\title{
Exogenous phosphorus compounds interact with nitrogen availability to regulate dynamics of soil inorganic phosphorus fractions in a meadow steppe
}

\author{
Heyong Liu ${ }^{1,2}$, Ruzhen Wang ${ }^{2}$, Hongyi Wang ${ }^{2}$, Yanzhuo Cao ${ }^{2,3}$, Feike A. Dijkstra ${ }^{4}$, Zhan Shi $^{2}$, Jiangping Cai ${ }^{2}$, \\ Zhengwen Wang ${ }^{2}$, Hongtao Zou ${ }^{1}$, and Yong Jiang ${ }^{2}$ \\ ${ }^{1}$ College of Land and Environment, Shenyang Agricultural University, Shenyang 110866, China \\ ${ }^{2}$ Erguna Forest-Steppe Ecotone Ecosystem Research Station, Institute of Applied Ecology, Chinese Academy of Sciences, \\ Shenyang 110016, China \\ ${ }^{3}$ Key Laboratory of Regional Environment and Eco-Remediation, College of Environment, Shenyang University, \\ Shenyang 110044, China \\ ${ }^{4}$ Centre for Carbon, Water and Food, School of Life and Environmental Sciences, The University of Sydney, \\ Sydney, NSW 2006, Australia
}

Correspondence: Ruzhen Wang (ruzhenwang @iae.ac.cn) and Hongtao Zou (zouhongtao2001@ @163.com)

Received: 6 May 2019 - Discussion started: 11 June 2019

Revised: 15 October 2019 - Accepted: 15 October 2019 - Published: 12 November 2019

\begin{abstract}
Here we investigated the effects of $\mathrm{P}$ compounds $\left(\mathrm{KH}_{2} \mathrm{PO}_{4}\right.$ and $\left.\mathrm{Ca}\left(\mathrm{H}_{2} \mathrm{PO}_{4}\right)_{2}\right)$ with different addition rates of $0,20,40,60,80$, and $100 \mathrm{~kg} \mathrm{Pha}^{-1} \mathrm{yr}^{-1}$ and $\mathrm{NH}_{4} \mathrm{NO}_{3}$ addition $\left(0\right.$ and $\left.100 \mathrm{~kg} \mathrm{~N} \mathrm{ha}^{-1} \mathrm{yr}^{-1}\right)$ on soil labile inorganic phosphorus (IP) (dicalcium phosphate, $\mathrm{Ca}_{2}-\mathrm{P}$ ), moderate-cycling IP, and recalcitrant IP fractions in a calcareous grassland of northeastern China. Soil moderate-cycling IP fractions, not readily available to plants but transforming into soil-available $\mathrm{P}$ quickly, include variscite (Al-P), strengite (Fe-P) and octacalcium phosphate $\left(\mathrm{Ca}_{8}-\mathrm{P}\right)$; recalcitrant IP fractions include hydroxylapatite $\left(\mathrm{Ca}_{10}-\mathrm{P}\right)$ and occluded $\mathrm{P}(\mathrm{O}-\mathrm{P})$. Soil labile and moderate-cycling IP fractions and total $\mathrm{P}$ significantly increased with increasing $\mathrm{P}$ addition rates, with higher concentrations detected for $\mathrm{KH}_{2} \mathrm{PO}_{4}$ than for $\mathrm{Ca}\left(\mathrm{H}_{2} \mathrm{PO}_{4}\right)_{2}$ addition. Combined $\mathrm{N}$ and $\mathrm{P}$ treatments showed lower soil labile IP and moderate-cycling IP fractions compared to ambient $\mathrm{N}$ conditions, due to enhanced plant productivity. Moderatecycling IP was mainly regulated by $\mathrm{P}$ addition and plant $\mathrm{P}$ uptake to further enhance labile IP and total $\mathrm{P}$ concentrations with $\mathrm{KH}_{2} \mathrm{PO}_{4}$ and $\mathrm{Ca}\left(\mathrm{H}_{2} \mathrm{PO}_{4}\right)_{2}$ addition. Soil labile IP was also directly and negatively affected by soil $\mathrm{pH}$ and plant $\mathrm{P}$ uptake with $\mathrm{Ca}\left(\mathrm{H}_{2} \mathrm{PO}_{4}\right)_{2}$ addition. $\mathrm{Ca}\left(\mathrm{H}_{2} \mathrm{PO}_{4}\right)_{2}$ addition significantly increased the soil recalcitrant IP $\left(\mathrm{Ca}_{10}-\mathrm{P}\right)$ fraction, while $\mathrm{KH}_{2} \mathrm{PO}_{4}$ addition showed no impact on it. A significant positive correlation was detected between soil labile IP,
\end{abstract}

moderate-cycling IP fractions and soil Olsen-P which illustrated that labile IP and moderate-cycling IP fractions were important sources for soil-available P. Our results suggest that moderate-cycling IP fractions are essential for grassland $\mathrm{P}$ biogeochemical cycling and the chemical form of $\mathrm{P}$ fertilizer should be considered during fertilization management for maintaining soil-available $\mathrm{P}$.

\section{Introduction}

Phosphorus (P) is an essential nutrient affecting terrestrial plant productivity and ecosystem functions (Luo et al., 2015). Soil inorganic P (IP) could occupy $50 \%-90 \%$ of soil total P (Jiang and Gu, 1989; Feng et al., 2016) and mainly includes adsorbed and mineral forms of phosphate (Hinsinger, 2001). Soil mineral-bound phosphate falls into two groups: those containing calcium (Ca-P) and those containing iron and aluminum (Chen et al., 2002), which are the leading sources of plant-available P (Meena et al., 2018). The detailed classification of these two groups includes soil variscite (Al-P), strengite (Fe-P), dicalcium phosphate $\left(\mathrm{Ca}_{2}-\right.$ $\mathrm{P})$, octacalcium phosphate $\left(\mathrm{Ca}_{8}-\mathrm{P}\right)$, hydroxylapatite $\left(\mathrm{Ca}_{10}-\mathrm{P}\right)$ and occluded P (O-P) (Zhao et al., 2019). Soil IP is dom- 
inated by Al-P and Fe-P in acidic soils and by Ca-P fractions in calcareous soils (Baumann et al., 2017). The solubility of soil Ca-P fractions decreases in the order $\mathrm{Ca}_{2}$ $\mathrm{P}>\mathrm{Ca}_{8}-\mathrm{P}>\mathrm{Ca}_{10}-\mathrm{P}$ (Jiang and $\mathrm{Gu}$, 1989). Although these element-bound $\mathrm{P}$ fractions are not readily available to plants, soil Al-P, Fe-P, $\mathrm{Ca}_{2}-\mathrm{P}$ and $\mathrm{Ca}_{8}-\mathrm{P}$ can be converted to free phosphates, serving as important buffering pools for available P (Herlihy and McGrath, 2006; Zhao et al., 2019). Based on $\mathrm{P}$ transforming dynamics, soil IP could be fractionated into soil labile $\left(\mathrm{Ca}_{2}-\mathrm{P}\right)$ or available $\mathrm{P}(\mathrm{Olsen}-\mathrm{P})$, moderatecycling $\mathrm{P}$ fractions (Al-P, Fe-P and $\left.\mathrm{Ca}_{8}-\mathrm{P}\right)$ and recalcitrant $\mathrm{P}$ fractions $\left(\mathrm{Ca}_{10}-\mathrm{P}\right.$ and $\left.\mathrm{O}-\mathrm{P}\right)$. But the category is not universal and mainly depends on the sensitivity of soil IP fractions in different studies (Schrijver et al., 2012 vs. Zhao et al., 2019). Soil Olsen-P could be directly absorbed and utilized by plants, which includes all water-soluble $\mathrm{P}$, some of the adsorbed and soluble IP, and mineralizable organic P (Tang et al., 2009; Cao et al., 2012). $\mathrm{Ca}_{2}-\mathrm{P}$, chemically similar to Olsen-P, includes water-soluble $\mathrm{P}$, citrate-soluble $\mathrm{P}$ and partially surface-adsorbed P (Shen et al., 2004; Zhao et al., 2019). Soil recalcitrant IP is relatively stable and unavailable for plants, which is mainly converted from the fixation of labile and moderate-cycling IP (Shen et al., 2004; Zhao et al., 2019). Therefore, soil IP transformation is crucial for nutrient cycling in terrestrial ecosystems.

Adding $\mathrm{P}$ to soil is an effective way to enhance soilavailable $\mathrm{P}$ and sustain plant productivity (Marklein and Houlton, 2012). However, $P$ addition changes ecosystem $P$ cycling (Herlihy and McGrath, 2006) and the reactions between free phosphate and cations in soil, thereby influencing the concentration and transformation of soil IP fractions (Walker and Syers, 1976). As such, chronic P input can result in insoluble phosphate accumulation and decrease $\mathrm{P}$ use efficiency without providing additional benefits for plant growth (Maistry et al., 2015; Halajnia et al., 2009; Maistry, 2015). This could then increase the risk of soil $\mathrm{P}$ leaching losses (Shen et al., 2004). Therefore, exploring the effect of $P$ addition on soil IP fractions is important for understanding soilavailable $\mathrm{P}$ supply and $\mathrm{P}$ dynamics in terrestrial ecosystems (Sigua et al., 2017).

Biogeochemical $\mathrm{P}$ dynamics can also be influenced by the chemical form of applied P (Margenot et al., 2017). Frequently used $\mathrm{P}$ compounds include $\mathrm{Ca}\left(\mathrm{H}_{2} \mathrm{PO}_{4}\right)_{2}$ (slowrelease $\mathrm{P}$ fertilizer) and $\mathrm{KH}_{2} \mathrm{PO}_{4}$ (fast-release $\mathrm{P}$ fertilizer) (Mortvedt et al., 1999), which have played critical roles in agricultural ecosystems (Nguyen et al., 2012). Both P fertilizers can convert into various inorganic $P$ fractions including soil Fe-P (especially in paddy soils with high $\mathrm{Fe}^{2+}$ ) (Sah et al., 1989) and soil Al-P, which can account for $33 \%$ of the total soil $\mathrm{P}$ in weathered soils (Margenot et al., 2017). Soil $\mathrm{Ca}_{2}-\mathrm{P}$ and $\mathrm{Ca}_{8}-\mathrm{P}$ could be also formed with $\mathrm{P}$ addition, especially in calcareous soils with $\mathrm{pH}$ higher than 7 (Al-Khateeb et al., 1986). In a previous study it was found that long-term application of $\mathrm{Ca}\left(\mathrm{H}_{2} \mathrm{PO}_{4}\right)_{2}$ increased soil IP fractions (Al$\mathrm{P}, \mathrm{Fe}-\mathrm{P}, \mathrm{Ca}_{2}-\mathrm{P}, \mathrm{Ca}_{8}-\mathrm{P}$ and $\left.\mathrm{O}-\mathrm{P}\right)$ and total $\mathrm{P}(\mathrm{TP})$ concentra- tions in a calcareous soil (Wang et al., 2010), and another study showed that long-term $\mathrm{Ca}\left(\mathrm{H}_{2} \mathrm{PO}_{4}\right)_{2}$ addition decreased soil $\mathrm{P}$ availability due to fixation of $\mathrm{P}$ to the soil constituents (Xiong et al., 2018). $\mathrm{KH}_{2} \mathrm{PO}_{4}$ addition was suggested to enhance the reaction of phosphate with $\mathrm{Fe}$ and $\mathrm{Al}$ oxides and with hydroxyl ions under lower soil $\mathrm{pH}$ conditions (Shuman, 1988). While these studies provided insight into the relationships between $\mathrm{P}$ addition and IP fractions (Condron and Goh, 1989), little is known about the effects of different $P$ compound additions on soil IP fractions and $\mathrm{P}$ availability.

Nitrogen enrichment can influence soil chemical properties, thereby affecting soil $\mathrm{P}$ transformations and consequently aboveground biomass and foliar $\mathrm{P}$ concentrations (Crowley et al., 2012). For instance, $\mathrm{N}$ addition often decreases soil $\mathrm{pH}$ and promotes the release of $\mathrm{P}$ from $\mathrm{Fe}$ and $\mathrm{Al}$ oxides (Gustafsson et al., 2012; Yang et al., 2014) and can result in redistribution of soil IP fractions (Zhao et al., 2019). Nitrogen addition could also promote the mineralization of soil organic $\mathrm{P}$ by increasing phosphatase activities (Olander and Vitousek, 2000). The effect of combined $\mathrm{N}$ and $\mathrm{P}$ addition on ecosystem $\mathrm{P}$ dynamics may further depend on their relative amounts added to the soil. For instance, inorganic $\mathrm{P}$ solubility and availability were particularly large when $\mathrm{P}$ was applied with $\mathrm{N}$ (Ross et al., 1995), while $\mathrm{N}$ and $\mathrm{P}$ applied at higher $\mathrm{N}: \mathrm{P}$ ratios increased plant $\mathrm{P}$ use efficiency and leaf phosphatase activity (Hogan et al., 2010). It is well known that variation in $\mathrm{N}: \mathrm{P}$ input ratios can also alter plant litter N : P ratios (Vitousek et al., 2010; Güsewell, 2004; Sun et al., 2018), thereby further affecting $N$ and $P$ availability through litter decomposition. However, it remains unclear how applications of $\mathrm{N}$ and $\mathrm{P}$ added at different ratios will affect soil IP fractions.

The meadow steppe in northern China is an important part of the Eurasian grassland ecosystem (Kang et al., 2007). With the intensive environmental stresses of overgrazing and enhanced outputs of animal products from a sharply rising population, Inner Mongolian grassland ecosystems have potentially become more nutrient-limited, predominantly in regards to N and P (Kang et al., 2007; Gong et al., 2011). Hence, $\mathrm{N}$ and $\mathrm{P}$ additions are necessary to enhance ecosystem productivity in the meadow steppe. The purpose of our study was to monitor the effects of various levels of $\mathrm{KH}_{2} \mathrm{PO}_{4}$ and $\mathrm{Ca}\left(\mathrm{H}_{2} \mathrm{PO}_{4}\right)_{2}$ with and without $\mathrm{N}$ addition on concentrations of soil IP fractions, available $\mathrm{P}$ and TP. We hypothesized that (1) soil labile IP $\left(\mathrm{Ca}_{2}-\mathrm{P}\right)$ and moderate-cycling IP fractions (Al-P, Fe-P and $\mathrm{Ca}_{8}-\mathrm{P}$ ) would significantly increase with $\mathrm{KH}_{2} \mathrm{PO}_{4}$ and $\mathrm{Ca}\left(\mathrm{H}_{2} \mathrm{PO}_{4}\right)_{2}$ addition, while soil recalcitrant IP fractions $\left(\mathrm{Ca}_{10}-\mathrm{P}\right.$ and O-P) would not be affected because of different solubility in IP fractions; (2) addition of soluble $\mathrm{KH}_{2} \mathrm{PO}_{4}$ would be more efficient in increasing soil labile IP, moderate-cycling IP fractions, recalcitrant $\mathrm{P}$ fractions, and total $\mathrm{P}(\mathrm{TP})$ than less soluble $\mathrm{Ca}\left(\mathrm{H}_{2} \mathrm{PO}_{4}\right)_{2}$ because of faster conversion of $\mathrm{KH}_{2} \mathrm{PO}_{4}$ into labile and moderatecycling IP fractions, consequentially promoting the formation of recalcitrant fractions; and (3) the concentrations of 
soil IP fractions would be lower under combined $\mathrm{P}$ and $\mathrm{N}$ additions than those under $\mathrm{P}$ addition alone due to facilitation of plant $\mathrm{P}$ uptake with $\mathrm{N}$ addition.

\section{Materials and methods}

\subsection{Study sites and experimental design}

The study site $\left(50^{\circ} 10^{\prime} \mathrm{N}, 119^{\circ} 22^{\prime} \mathrm{E}\right.$, elevation $523 \mathrm{~m}$ a.s.l. $)$ is located at the Erguna Forest-Steppe Ecotone Research Station of Inner Mongolia, China. This area belongs to a temperate continental monsoon climate. The mean annual precipitation and mean annual temperature are $375 \mathrm{~mm}$ and $-3^{\circ} \mathrm{C}$, respectively. Rainfall at the site is mainly concentrated during the period from June to August and the average growing season is about $150 \mathrm{~d}$. The soil is a chernozem according to the Food and Agricultural Organization of the United Nations classification (IUSS Working Group WRB, 2014), and the soil chemical characteristics of the site are reported in Table 1. The dominant plant species include Stipa baicalensis, Leymus chinensis and Carex duriuscula. The relative biomass proportion of the three dominant species combined to the total aboveground biomass were $50.29 \%-74.75 \%$ and $72.43 \%-91.92 \%$ in the plots without and with $\mathrm{N}$ addition, respectively.

The experiment, established in 2014, was arranged in a randomized block design with 24 treatments and five replicates. Phosphorus addition included two compounds, i.e., $\mathrm{KH}_{2} \mathrm{PO}_{4}$ and $\mathrm{Ca}\left(\mathrm{H}_{2} \mathrm{PO}_{4}\right)_{2}$, and were applied at six levels: 0, $20,40,60,80$ and $100 \mathrm{~kg} \mathrm{Pha}^{-1} \mathrm{yr}^{-1}$. Half of the plots were applied with $100 \mathrm{~kg} \mathrm{Nha}^{-1} \mathrm{yr}^{-1}$ in the form of $\mathrm{NH}_{4} \mathrm{NO}_{3}$. $\mathrm{P}$ and $\mathrm{N}$ were added in the middle of May. All treatment plots were balanced for $\mathrm{K}$ using potassium chloride $(\mathrm{KCl})$ to maintain the same amount of $\mathrm{K}$ input as in the treatment with $100 \mathrm{~kg} \mathrm{Pha}^{-1} \mathrm{yr}^{-1}$ of $\mathrm{KH}_{2} \mathrm{PO}_{4}$ addition $\left(132 \mathrm{~kg} \mathrm{Kha}^{-1}\right)$. To balance for $\mathrm{Cl}$ along with $\mathrm{KCl}$ addition, $\mathrm{CaCl}_{2}$ was applied to maintain equal $\mathrm{Cl}$ inputs for all plots $\left(121 \mathrm{~kg} \mathrm{Cl} \mathrm{ha}^{-1}\right)$. Calcium was not balanced in this calcareous soil, where $\mathrm{Ca}$ is already abundant. In this study we chose the same control plots for the $\mathrm{KH}_{2} \mathrm{PO}_{4}$ and $\mathrm{Ca}\left(\mathrm{H}_{2} \mathrm{PO}_{4}\right)_{2}$ treatment, so that, in total, there were 110 plots of $8 \mathrm{~m} \times 8 \mathrm{~m}$, separated by $1 \mathrm{~m}$ wide buffer zones. The initial $\mathrm{pH}$ of $\mathrm{KH}_{2} \mathrm{PO}_{4}$ and $\mathrm{Ca}\left(\mathrm{H}_{2} \mathrm{PO}_{4}\right)_{2}$ solutions were 4.91 and 4.50 , respectively.

\subsection{Sample collection}

In August 2016, aboveground biomass was harvested by clipping all living tissues using a $1 \mathrm{~m} \times 1 \mathrm{~m}$ quadrat placed randomly within each plot. The plants were sorted to species and oven-dried at $65^{\circ} \mathrm{C}$ for $48 \mathrm{~h}$, then weighed and ground. Soil samples were taken from the surface $(10 \mathrm{~cm}$ depth) using a $5 \mathrm{~cm}$ diameter soil auger. Five soil cores were collected from each plot and mixed into one composite sample. Each sample was air-dried and passed through a $2 \mathrm{~mm}$ sieve to remove litter and detritus. A subsample of the air-dried soil was ground using a ball mill to pass through a $0.15 \mathrm{~mm}$ sieve for further analyses of IP fractions and TP.

\subsection{Soil chemical analyses}

Soil $\mathrm{pH}$ was measured in a $1: 5$ soil-to-water slurry with a pH meter (S210 SevenCompact ${ }^{\mathrm{TM}}$, Mettler, Germany). Soil IP fractions were extracted according to the sequential fractionation scheme proposed by Chang and Jackson (1958) which is modified to suit for calcareous soils (Jiang and $\mathrm{Gu}$, 1989). Briefly, soil $\mathrm{Ca}_{2}-\mathrm{P}$ was determined by shaking $0.5 \mathrm{~g}$ soil with $25 \mathrm{~mL} 0.25 \mathrm{MNaHCO}_{3}(\mathrm{pH} 7.5)$ and then centrifuged at $3500 \mathrm{rpm}$ for $8 \mathrm{~min}$ to measure soil $\mathrm{Ca}_{2}-\mathrm{P}$. The remaining soil was washed two times with $25 \mathrm{~mL} 95 \%$ $\mathrm{C}_{2} \mathrm{H}_{5} \mathrm{OH}$ and extracted with $25 \mathrm{~mL} 0.5 \mathrm{M} \mathrm{NH}_{4} \mathrm{Ac}(\mathrm{pH}=4.2)$ to determine soil $\mathrm{Ca}_{8}-\mathrm{P}$ (Jiang and $\mathrm{Gu}, 1989$ ). After this,

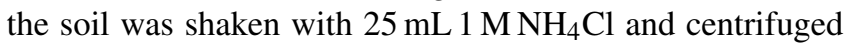
at $3500 \mathrm{rpm}$ to discard the supernatant. The remaining soil was then shaken with $25 \mathrm{~mL} 0.5 \mathrm{M} \mathrm{NH}_{4} \mathrm{~F}(\mathrm{pH} 8.2)$ and centrifuged at $3500 \mathrm{rpm}$ for $8 \mathrm{~min}$ to analyze the soil Al-P fraction in the supernatant. The remaining soil was washed two times with $25 \mathrm{~mL}$ saturated $\mathrm{NaCl}$ and then sequentially shaken with $25 \mathrm{~mL}$ mixture of $0.1 \mathrm{M} \mathrm{NaOH}$ and $\mathrm{Na}_{2} \mathrm{CO}_{3}$ for $2 \mathrm{~h}$ at $25^{\circ} \mathrm{C}$ and then centrifuged at $4500 \mathrm{rpm}$ for $10 \mathrm{~min}$ to measure soil Fe-P in the supernatant. The remaining samples were washed as above and extracted with $25 \mathrm{~mL}$ mixture of $0.3 \mathrm{M} \mathrm{Na}_{3}$ (citrate) $-\mathrm{Na}_{2} \mathrm{~S}_{2} \mathrm{O}_{4}$ and $0.5 \mathrm{M} \mathrm{NaOH}$ to measure soil O-P. Finally, the remaining samples were shaken with $0.25 \mathrm{M} \mathrm{H}_{2} \mathrm{SO}_{4}$ for $1 \mathrm{~h}$ at $25^{\circ} \mathrm{C}$ and centrifuged at $3800 \mathrm{rpm}$ for $10 \mathrm{~min}$ to determine soil $\mathrm{Ca}_{10}-\mathrm{P}$. The $\mathrm{P}$ concentration in all the extractants was determined by the molybdenum blue colorimetric method at a wavelength of $700 \mathrm{~nm}$ with a UVVIS spectrometer (UV-1700, Shimadzu) (Murphy and Riley, 1962). Soil total IP (TIP) concentration was defined as the sum of soil labile IP $\left(\mathrm{Ca}_{2}-\mathrm{P}\right)$, moderate-cycling IP (Al-P, Fe$\mathrm{P}$ and $\left.\mathrm{Ca}_{8}-\mathrm{P}\right)$ and recalcitrant IP $\left(\mathrm{Ca}_{10}-\mathrm{P}\right.$ and $\left.\mathrm{O}-\mathrm{P}\right)$. Total organic $\mathrm{P}$ (TOP) was calculated as the difference between TP and TIP concentrations. The potential limitation of the extraction methods is that they may not be very specific in separating the different forms of $\mathrm{P}$ minerals, as a small amount of other phosphates dissolved in the extractants (Jiang and $\mathrm{Gu}, 1989$ ).

Soil TP concentration was determined after digestion with $8 \mathrm{~mL} 85 \% \mathrm{HNO}_{3}+4 \mathrm{~mL} 72 \% \mathrm{HClO}_{4}+1 \mathrm{~mL} 40 \% \mathrm{HF}$ (Sommers and Nelson, 1972), and Olsen-P was extracted from air-dried soil with $0.5 \mathrm{M} \mathrm{NaHCO}_{3}(\mathrm{pH}$ 8.5) (Olsen et al., 1954). Plant TP concentration was determined by acid digestion using $\mathrm{H}_{2} \mathrm{SO}_{4}-\mathrm{H}_{2} \mathrm{O}_{2}$ (Thomas et al., 1967). Soil TP, Olsen-P and plant TP were analyzed by the molybdenum blue colorimetric method at $700 \mathrm{~nm}$. 
Table 1. General characteristics of the soil from the experimental site before nitrogen and phosphorus manipulation. Selected parameters include sand, silt, and clay fractions; soil pH; soil organic matter (SOM); total nitrogen (TN); total phosphorus (TP); total inorganic phosphorus (TIP); organic P; exchangeable $\mathrm{Ca}$ and $\mathrm{Al}$; and available Fe and Mn. Data are mean \pm standard error $(n=5)$.

\begin{tabular}{lrrrrrrrrrrr}
\hline $\begin{array}{l}\text { Sand } \\
(\%)\end{array}$ & $\begin{array}{r}\text { Silt } \\
(\%)\end{array}$ & $\begin{array}{r}\text { Clay } \\
(\%)\end{array}$ & $\begin{array}{r}\text { Soil } \\
\mathrm{pH}\end{array}$ & $\begin{array}{r}\mathrm{SOM} \\
\left(\mathrm{g} \mathrm{kg}^{-1}\right)\end{array}$ & $\begin{array}{r}\mathrm{TN} \\
\left(\mathrm{g} \mathrm{kg}^{-1}\right)\end{array}$ & $\begin{array}{r}\mathrm{TP} \\
\left(\mathrm{mg} \mathrm{kg}^{-1}\right)\end{array}$ & $\begin{array}{r}\mathrm{TIP} \\
\left(\mathrm{mg} \mathrm{kg}^{-1}\right)\end{array}$ & $\begin{array}{r}\text { Organic P } \\
\left(\mathrm{mg} \mathrm{kg}^{-1}\right)\end{array}$ & $\begin{array}{r}\mathrm{Ca} \\
\left(\mathrm{cmol} \mathrm{kg}^{-1}\right)\end{array}$ & $\begin{array}{r}\mathrm{Al} \\
\left(\mathrm{cmol} \mathrm{kg}^{-1}\right)\end{array}$ & $\begin{array}{r}\mathrm{Fe} \\
\left(\mathrm{mg} \mathrm{kg}^{-1}\right)\end{array}$ \\
\hline 36.75 & 39.61 & 23.64 & 6.68 & 43.89 & 1.83 & 508.23 & 105.05 & 403.17 & $\begin{array}{r}\mathrm{Mn} \\
\left(\mathrm{mg} \mathrm{kg}^{-1}\right)\end{array}$ \\
\pm 0.93 & \pm 0.96 & \pm 0.78 & \pm 0.06 & \pm 1.14 & \pm 0.06 & \pm 21.30 & \pm 2.87 & \pm 22.95 & \pm 0.43 & $\begin{array}{r}0.05 \\
\pm 0.01\end{array}$ & $\begin{array}{r}36.76 \\
\pm 1.77\end{array}$ \\
\hline
\end{tabular}

\subsection{Statistical analyses}

Plant P uptake of three dominant species was calculated using the following equation:

$\mathrm{P}$ uptake $=\sum_{i}^{n} P_{i} \times B_{i}$,

where $P_{i}$ is TP concentration of species $i$ and $B_{i}$ is the biomass of species $i$. All the data were shown as mean \pm standard error. The Kolmogorov-Smirnov test was performed to determine whether the data had a normal distribution. Three-way ANOVAs were conducted to determine the effects of $\mathrm{N}$ addition $(N), \mathrm{P}$ addition rate $\left(P_{\mathrm{r}}\right), \mathrm{P}$ compounds $\left(P_{\mathrm{t}}\right)$ and their interactions on soil IP fractions and Olsen-P concentration. For each $\mathrm{P}$ compound and $\mathrm{N}$ treatment, the effect of $\mathrm{P}$ addition rates on moderate-cycling IP fractions and plant $\mathrm{P}$ were determined using polynomial contrasts, the effect of $\mathrm{P}$ addition rates on plant biomass, soil $\mathrm{pH}$, soil recalcitrant IP fractions, Olsen-P and TP were analyzed using Duncan's multiple-range tests. A Student's $t$ test was used to determine the difference between two P compounds within each $\mathrm{P}$ addition rate and $\mathrm{N}$ treatment (without and with $\mathrm{N}$ ) and between $\mathrm{N}$ treatments within each $\mathrm{P}$ compound and addition rate. For moderate-cycling IP fractions, one-way analysis of covariance (ANCOVA) was employed to distinguish the slopes between the two $\mathrm{N}$ treatments (without $\mathrm{N}$ vs. with $\mathrm{N}$ ) for each $\mathrm{P}$ compound and between the two $\mathrm{P}$ compounds $\left(\mathrm{KH}_{2} \mathrm{PO}_{4}\right.$ vs. $\left.\mathrm{Ca}\left(\mathrm{H}_{2} \mathrm{PO}_{4}\right)_{2}\right)$ for each $\mathrm{N}$ treatment. Pearson correlations were used to test the relationships between soil variables. All of the above statistics were carried out using SPSS 16.0 (SPSS Inc., Chicago, USA).

Structural equation models (SEMs) were built to clarify direct and indirect $\mathrm{N}$ and $\mathrm{P}$ addition effects on soil IP fractions through the changes in plant $\mathrm{P}$ uptake and soil $\mathrm{pH}$. A chi-square test, Akaike information criteria (AIC) and rootmean-square error of approximation (RMSEA) were used to evaluate the fit of the model. The SEM analyses were performed using AMOS 7.0 (Amos Development Co., Greene, Maine, USA). Statistical significance was accepted at $P<$ 0.05 .

\section{Results}

\subsection{Aboveground plant biomass and soil $\mathrm{pH}$}

Nitrogen addition increased aboveground biomass production (Fig. 1a, b). Aboveground biomass production did not show a clear trend in response to different levels of $\mathrm{P}$ addition, either as $\mathrm{KH}_{2} \mathrm{PO}_{4}$ or as $\mathrm{Ca}\left(\mathrm{H}_{2} \mathrm{PO}_{4}\right)_{2}$ (Fig. 1a, b). Nitrogen addition significantly increased plant $\mathrm{P}$ uptake of the three dominant species Stipa baicalensis, Leymus chinensis and Carex duriuscula for both P compounds (Fig. 1c, d). Plant $\mathrm{P}$ uptake increased with increasing $\mathrm{P}$ addition rates with significantly higher overall $\mathrm{KH}_{2} \mathrm{PO}_{4}$ effect than $\mathrm{Ca}\left(\mathrm{H}_{2} \mathrm{PO}_{4}\right)_{2} . \mathrm{KH}_{2} \mathrm{PO}_{4}$ addition showed no impact on soil $\mathrm{pH}$ (Fig. 1e), while $\mathrm{Ca}\left(\mathrm{H}_{2} \mathrm{PO}_{4}\right)_{2}$ tended to decrease soil $\mathrm{pH}$ at 80 and $100 \mathrm{~kg} \mathrm{Pha}^{-1} \mathrm{yr}^{-1}$ without $\mathrm{N}$ addition and at 60 , 80 and $100 \mathrm{~kg} \mathrm{Pha}^{-1} \mathrm{yr}^{-1}$ with $\mathrm{N}$ addition (Fig. 1f).

\subsection{Soil labile and moderate-cycling inorganic phosphorus fractions}

For both $\mathrm{KH}_{2} \mathrm{PO}_{4}$ and $\mathrm{Ca}\left(\mathrm{H}_{2} \mathrm{PO}_{4}\right)_{2}$ additions, soil Al-P and Fe-P concentrations significantly increased with increased $P$ addition rates (Fig. 2a, b, c, d). Soil Al-P and Fe-P concentrations were higher with $\mathrm{KH}_{2} \mathrm{PO}_{4}$ than with $\mathrm{Ca}\left(\mathrm{H}_{2} \mathrm{PO}_{4}\right)_{2}$ addition, especially at higher $\mathrm{P}$ rates (Fig. 2; Table $\mathrm{S} 1$ in the Supplement). This resulted in significant interactive $P_{\mathrm{t}} \times P_{\mathrm{r}}$ effects on soil Al-P and Fe-P concentrations (Table 2). Significant interactive $P_{\mathrm{r}} \times N$ and $P_{\mathrm{t}} \times P_{\mathrm{r}} \times N$ effects were also found on soil Al-P. For instance, Al-P concentration was higher with $\mathrm{KH}_{2} \mathrm{PO}_{4}$ addition than $\mathrm{Ca}\left(\mathrm{H}_{2} \mathrm{PO}_{4}\right)_{2}$ at $\mathrm{P}$ addition level of $60 \mathrm{~kg} \mathrm{Pha}^{-1} \mathrm{yr}^{-1}$ when $\mathrm{N}$ was not added, but it was higher for $\mathrm{P}$ addition levels of 60,80 and $100 \mathrm{~kg} \mathrm{Pha}^{-1} \mathrm{yr}^{-1}$ when $\mathrm{N}$ was added. Nitrogen addition decreased both soil Al$\mathrm{P}$ and Fe-P concentrations, particularly at higher levels of $\mathrm{P}$ addition (Fig. 2; Tables 2 and S1).

Addition of both $\mathrm{P}$ compounds significantly increased soil $\mathrm{Ca}_{2}-\mathrm{P}$ and $\mathrm{Ca}_{8}-\mathrm{P}$ concentrations with and without $\mathrm{N}$ addition (Fig. 3a, b, c, d). With $\mathrm{KH}_{2} \mathrm{PO}_{4}$ addition, soil $\mathrm{Ca}_{2}-\mathrm{P}$ and $\mathrm{Ca}_{8}-$ $\mathrm{P}$ concentrations were higher than with $\mathrm{Ca}\left(\mathrm{H}_{2} \mathrm{PO}_{4}\right)_{2}$ addition (Fig. 3; Table S1). Nitrogen addition significantly decreased soil $\mathrm{Ca}_{2}-\mathrm{P}$ and $\mathrm{Ca}_{8}-\mathrm{P}$ concentrations for both $\mathrm{P}$ compounds in some $\mathrm{P}$ addition levels (Fig. 3; Table $\mathrm{S} 1$ ). Therefore, significant $P_{\mathrm{t}} \times P_{\mathrm{r}}$ interactive effects were detected on soil $\mathrm{Ca}_{2}-\mathrm{P}$ and $\mathrm{Ca}_{8}-\mathrm{P}$ and $P_{\mathrm{r}} \times N$ interactive effect on soil $\mathrm{Ca}_{2}-\mathrm{P}(\mathrm{Ta}-$ ble 2). 


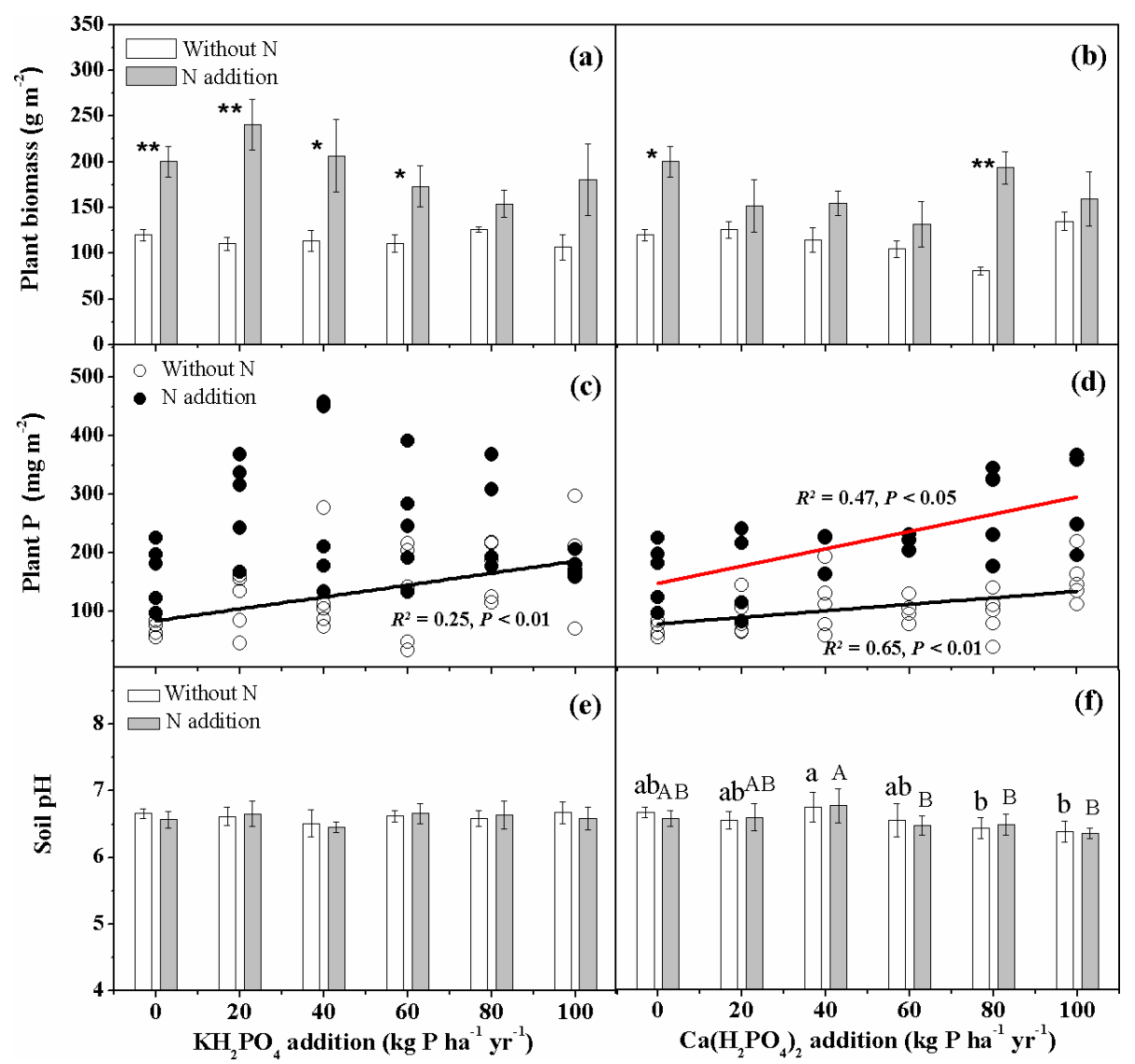

Figure 1. Aboveground plant biomass (a, b), biomass-weighted phosphorus (P) uptake of three dominant plant species (c, d) and soil pH (e, f) as affected by $\mathrm{KH}_{2} \mathrm{PO}_{4}$ and $\mathrm{Ca}\left(\mathrm{H}_{2} \mathrm{PO}_{4}\right)_{2}$ additions with and without $\mathrm{N}$ inputs. Data are represented as mean \pm standard error for panels (a), (b), (e) and (f). Letters indicate significant differences between $\mathrm{P}$ rates of $\mathrm{KH}_{2} \mathrm{PO}_{4}$ or $\mathrm{Ca}\left(\mathrm{H}_{2} \mathrm{PO}_{4}\right)_{2}$ addition without $\mathrm{N}$ (lowercase letters) and with $\mathrm{N}$ addition (capital letters). Asterisks represent significance between $\mathrm{N}$ treatments within each $\mathrm{P}$ type and rate $\left({ }^{*}\right.$ and ${ }^{* *}$ for $P<0.05$ and 0.01 , respectively).

Table 2. Results ( $F$ values) of three-way ANOVAs on the effect of phosphorus $(\mathrm{P})$ fertilizer type $\left(P_{\mathrm{t}}\right), \mathrm{P}$ addition rate $\left(P_{\mathrm{r}}\right)$, and nitrogen $(N)$ addition and their interactions on soil inorganic phosphorus fractions of variscite (Al-P), strengite $(\mathrm{Fe}-\mathrm{P})$, dicalcium phosphate $(\mathrm{Ca} 2-\mathrm{P})$, octacalcium phosphate $\left(\mathrm{Ca}_{8}-\mathrm{P}\right)$, hydroxylapatite $\left(\mathrm{Ca}_{10}-\mathrm{P}\right)$, occluded phosphate $(\mathrm{O}-\mathrm{P})$, Olsen-P, total inorganic phosphorus (TIP), and soil total $\mathrm{P}(\mathrm{TP})$ with $\mathrm{KH}_{2} \mathrm{PO}_{4}$ and $\mathrm{Ca}\left(\mathrm{H}_{2} \mathrm{PO}_{4}\right)_{2}$ addition.

\begin{tabular}{lrrrrrrrrr}
\hline & $\mathrm{Al}-\mathrm{P}$ & $\mathrm{Fe}-\mathrm{P}$ & $\mathrm{Ca}_{2}-\mathrm{P}$ & $\mathrm{Ca}-\mathrm{P}$ & $\mathrm{Ca}_{10}-\mathrm{P}$ & $\mathrm{O}-\mathrm{P}$ & Olsen-P & $\mathrm{TIP}$ & $\mathrm{TP}$ \\
\hline$P_{\mathrm{t}}$ & $32.4^{* *}$ & $76.7^{* *}$ & $59.9^{* *}$ & $101^{* *}$ & $98.1^{* *}$ & 0.60 & $21.5^{* *}$ & $60.4^{* *}$ & 2.90 \\
$P_{\mathrm{r}}$ & $268^{* *}$ & $97.3^{* *}$ & $73.8^{* *}$ & $62.6^{* *}$ & $6.30^{* *}$ & $3.88^{*}$ & $25.0^{* *}$ & $192^{* *}$ & $7.70^{* *}$ \\
$N$ & $37.1^{* *}$ & $18.2^{* *}$ & $11.1^{* *}$ & $21.9^{* *}$ & $5.20^{*}$ & 0.00 & 1.90 & $36.8^{* *}$ & 3.80 \\
$P_{\mathrm{t}} \times P_{\mathrm{r}}$ & $7.90^{* *}$ & $3.40^{*}$ & $11.6^{* *}$ & $8.40^{* *}$ & 1.00 & $3.21^{*}$ & $5.90^{* *}$ & $13.6^{* *}$ & 0.90 \\
$P_{\mathrm{t}} \times N$ & 0.40 & 0.10 & 5.30 & 6.20 & 0.10 & $19.7^{* *}$ & 1.80 & 0.00 & $6.00^{*}$ \\
$P_{\mathrm{r}} \times N$ & $6.30^{* *}$ & 2.10 & $2.70^{*}$ & 2.20 & 0.60 & 0.70 & 2.00 & $4.90^{* *}$ & 0.80 \\
$P_{\mathrm{t}} \times P_{\mathrm{r}} \times N$ & $4.20^{* *}$ & $2.60^{*}$ & 0.90 & $4.00^{* *}$ & 0.40 & $2.81^{*}$ & 1.30 & $3.40^{* *}$ & $3.90^{* *}$ \\
\hline
\end{tabular}

* Significance level at $0.05 . * *$ Significance level at 0.01 .

\subsection{Soil recalcitrant inorganic phosphorus fractions}

$\mathrm{Ca}\left(\mathrm{H}_{2} \mathrm{PO}_{4}\right)_{2}$ addition significantly increased soil $\mathrm{Ca}_{10}-\mathrm{P}$ concentration, while $\mathrm{KH}_{2} \mathrm{PO}_{4}$ addition showed no impact (Fig. 4a, b). Soil $\mathrm{Ca}_{10}-\mathrm{P}$ concentration was higher with
$\mathrm{Ca}\left(\mathrm{H}_{2} \mathrm{PO}_{4}\right)_{2}$ addition than with $\mathrm{KH}_{2} \mathrm{PO}_{4}$ addition for all levels except for $60 \mathrm{~kg} \mathrm{Pha}^{-1} \mathrm{yr}^{-1}$ without $\mathrm{N}$ addition and for 20, 60 and $80 \mathrm{~kg} \mathrm{Pha}^{-1} \mathrm{yr}^{-1}$ with $\mathrm{N}$ addition (Fig. 4a, b; Table S2). There was no main $\mathrm{N}$ addition and $N \times P_{\mathrm{r}}$ interactive effect on soil $\mathrm{Ca}_{10}-\mathrm{P}$ for both $\mathrm{P}$ compounds (Table 2). 


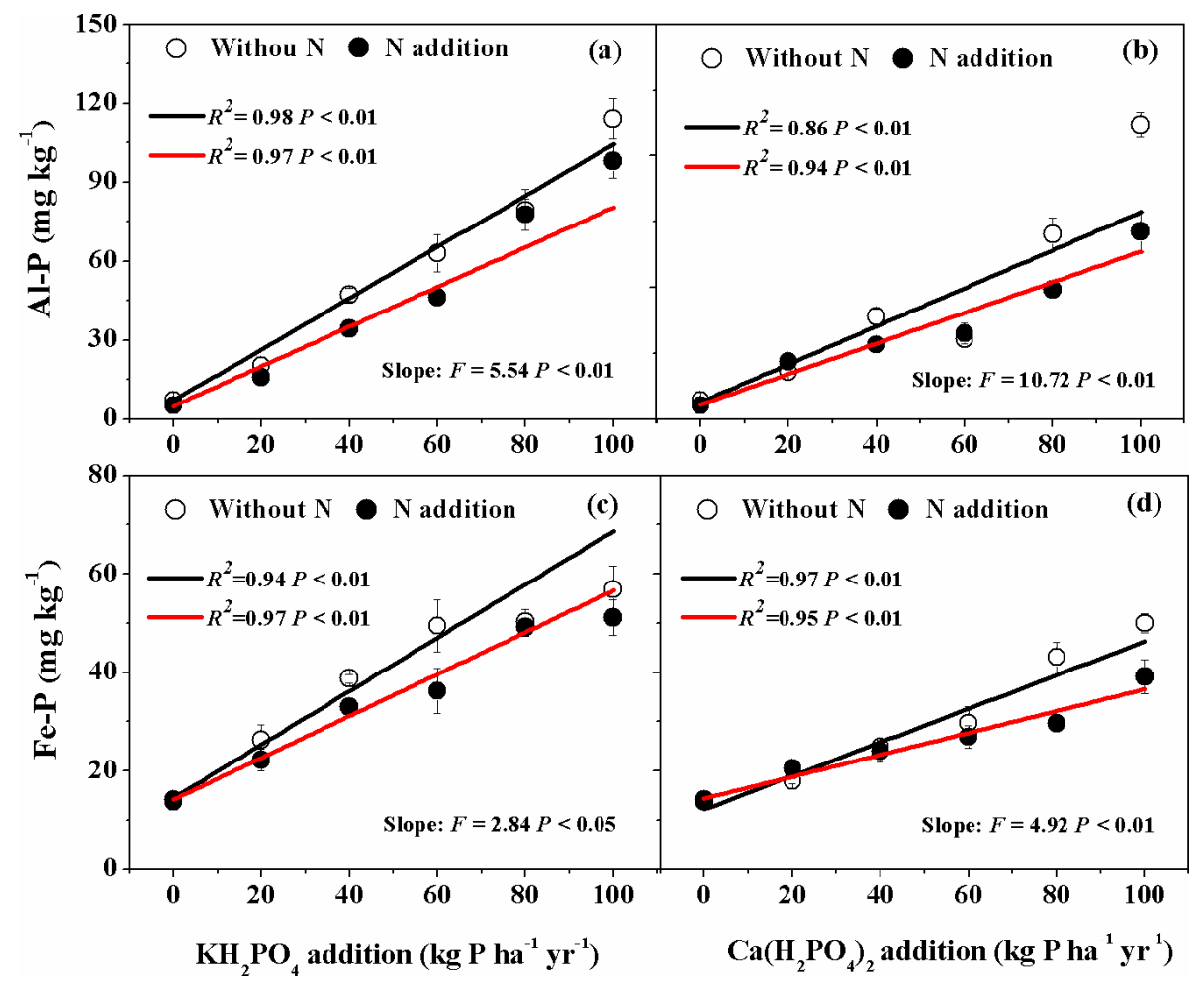

Figure 2. Effects of phosphorus $(\mathrm{P})$ and nitrogen $(\mathrm{N})$ additions on soil variscite $(\mathrm{Al}-\mathrm{P})$ and strengite $(\mathrm{Fe}-\mathrm{P})$. Data are represented as mean \pm standard error. Phosphorus types include $\mathrm{KH}_{2} \mathrm{PO}_{4}$ and $\mathrm{Ca}\left(\mathrm{H}_{2} \mathrm{PO}_{4}\right)_{2}$ at rates of $0,20,40,60,80$ and $100 \mathrm{~kg} \mathrm{Pha}^{-1} \mathrm{yr}^{-1}$. Fitted lines are based on linear regression models. The black and red lines represent without $\mathrm{N}$ and $\mathrm{N}$ addition, respectively. Significance is labeled for slopes of the black and red lines.

Nitrogen addition also had no significant effect on soil O$\mathrm{P}$ with $\mathrm{KH}_{2} \mathrm{PO}_{4}$ addition but significantly decreased it with $\mathrm{Ca}\left(\mathrm{H}_{2} \mathrm{PO}_{4}\right)_{2}$ addition at 60 and $80 \mathrm{~kg} \mathrm{Pha}^{-1} \mathrm{yr}^{-1}$ (Fig. $4 \mathrm{c}$, d). Soil O-P showed a hump-shaped relationship along the $\mathrm{P}$ addition gradient with $\mathrm{KH}_{2} \mathrm{PO}_{4}$ when added with $\mathrm{N}$ and with $\mathrm{Ca}\left(\mathrm{H}_{2} \mathrm{PO}_{4}\right)_{2}$ independent of $\mathrm{N}$ addition. Soil O-P concentration was lower with $\mathrm{Ca}\left(\mathrm{H}_{2} \mathrm{PO}_{4}\right)_{2}$ addition than with $\mathrm{KH}_{2} \mathrm{PO}_{4}$ addition for 60 and $80 \mathrm{~kg} \mathrm{Pha}^{-1} \mathrm{yr}^{-1}$ with $\mathrm{N}$ addition (Fig. 4c, d; Table S2). The relative proportions of soil $\mathrm{O}-\mathrm{P}$ and $\mathrm{Ca}_{10}-\mathrm{P}$ to soil TIP decreased while the proportions of soil $\mathrm{Al}-\mathrm{P}, \mathrm{Ca}_{2}-\mathrm{P}$, and $\mathrm{Ca}_{8}-\mathrm{P}$ increased with increasing $\mathrm{P}$ addition rates for both $\mathrm{P}$ compounds (Fig. $\mathrm{S} 1$ in the Supplement).

\subsection{Soil Olsen-P and total $P$}

For both $\mathrm{P}$ compounds, $\mathrm{P}$ addition significantly increased soil Olsen-P concentration regardless of $\mathrm{N}$ addition (Fig. 5a, b). Soil Olsen-P concentration increased more strongly with increased levels of $\mathrm{KH}_{2} \mathrm{PO}_{4}$ addition than with $\mathrm{Ca}\left(\mathrm{H}_{2} \mathrm{PO}_{4}\right)_{2}$ addition, resulting in significantly higher soil Olsen-P with $\mathrm{KH}_{2} \mathrm{PO}_{4}$ addition in the $100 \mathrm{~kg} \mathrm{Pha}^{-1} \mathrm{yr}^{-1}$ treatment with and without $\mathrm{N}$ addition (Fig. $5 \mathrm{a}, \mathrm{b}$ ). $\mathrm{KH}_{2} \mathrm{PO}_{4}$ addition increased soil TP irrespective of $\mathrm{N}$ addition, while
$\mathrm{Ca}\left(\mathrm{H}_{2} \mathrm{PO}_{4}\right)_{2}$ addition only increased soil $\mathrm{TP}$ without $\mathrm{N}$ addition (Fig. 5c, d).

\subsection{Correlation between soil inorganic fractions with soil characteristics}

For both $\mathrm{P}$ compounds, soil $\mathrm{Al}-\mathrm{P}, \mathrm{Fe}-\mathrm{P}, \mathrm{Ca}_{2}-\mathrm{P}$ and $\mathrm{Ca}_{8}-\mathrm{P}$ had significantly positive correlations with each other. In addition, soil TP and Olsen-P were all positively correlated with soil Al-P, Fe-P, $\mathrm{Ca}_{2}-\mathrm{P}$ and $\mathrm{Ca}_{8}-\mathrm{P}(P<0.01)$ (Table 3). Soil $\mathrm{Ca}_{10}-\mathrm{P}$ had significantly positive correlations with soil $\mathrm{Fe}-$ $\mathrm{P}$ and $\mathrm{Ca}_{8}-\mathrm{P}$ for both $\mathrm{P}$ compounds (Table 3 ). Soil TOP had significantly positive correlations with soil TP (Table 3). Furthermore, soil TIP concentration was positively correlated with the level of $\mathrm{P}$ addition for both $\mathrm{P}$ compounds (Fig. S2).

The SEM suggested that $\mathrm{P}$ addition had a positive impact on plant $\mathrm{P}$ uptake and soil moderate-cycling IP both with $\mathrm{KH}_{2} \mathrm{PO}_{4}$ (Fig. 6a) and with $\mathrm{Ca}\left(\mathrm{H}_{2} \mathrm{PO}_{4}\right)_{2}$ addition (Fig. 6b). $\mathrm{N}$ addition had a positive impact on plant $\mathrm{P}$ uptake under both $\mathrm{P}$ compound additions (Fig. 6a, b). Plant $\mathrm{P}$ uptake had a negative impact on soil moderate-cycling IP both with $\mathrm{KH}_{2} \mathrm{PO}_{4}$ (Fig. 6a) and with $\mathrm{Ca}\left(\mathrm{H}_{2} \mathrm{PO}_{4}\right)_{2}$ addition (Fig. 6b), while soil $\mathrm{pH}$ also negatively influenced soil labile IP with $\mathrm{Ca}\left(\mathrm{H}_{2} \mathrm{PO}_{4}\right)_{2}$. Soil moderate-cycling IP fractions drove the increase in soil labile IP concentration for both $\mathrm{P}$ compounds, 

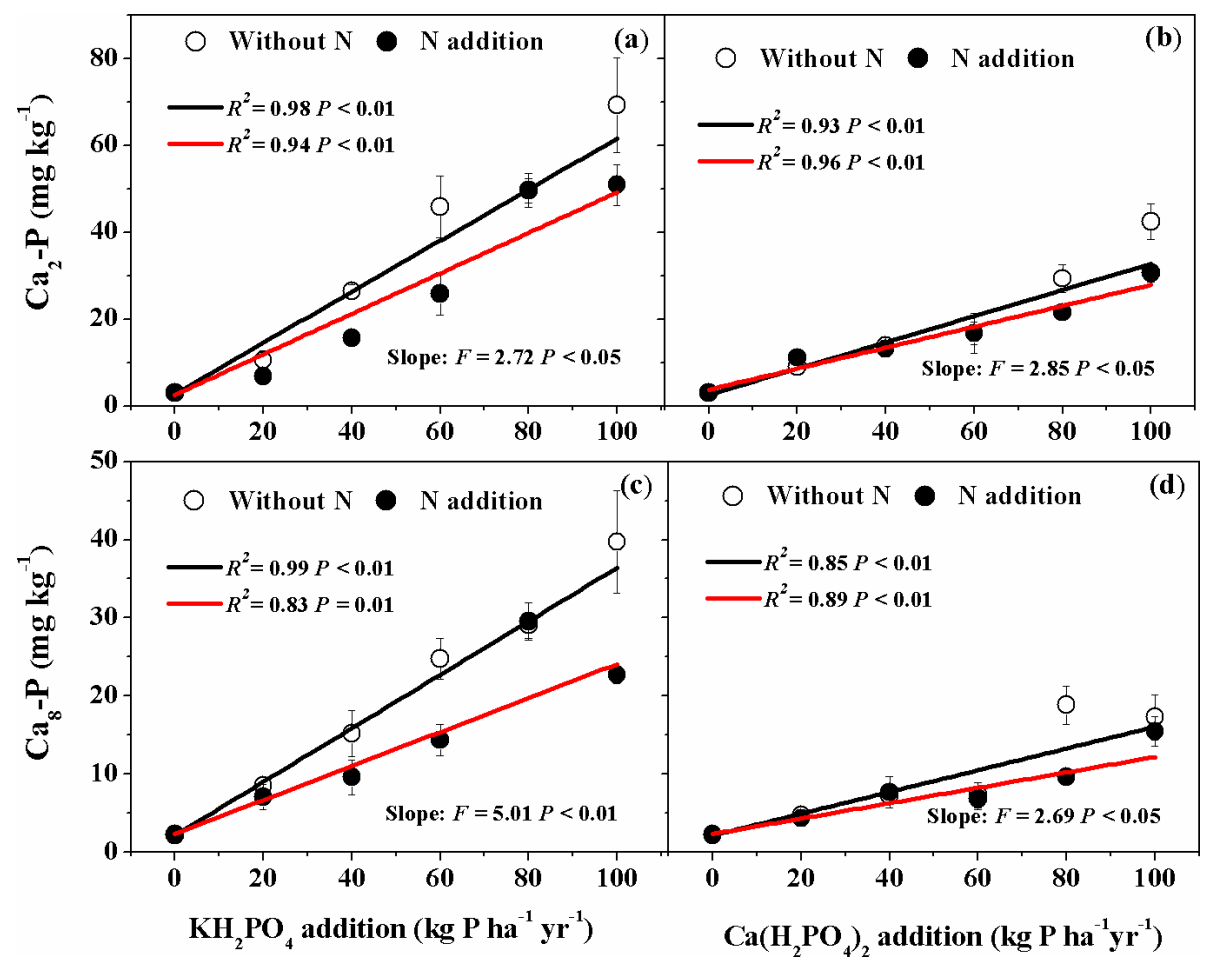

Figure 3. Effects of phosphorus $(\mathrm{P})$ and nitrogen $(\mathrm{N})$ additions on soil dicalcium phosphate $\left(\mathrm{Ca}_{2}-\mathrm{P}\right)$ and octacalcium phosphate $\left(\mathrm{Ca}_{8}\right.$ P). Phosphorus types include $\mathrm{KH}_{2} \mathrm{PO}_{4}$ and $\mathrm{Ca}\left(\mathrm{H}_{2} \mathrm{PO}_{4}\right)_{2}$ at rates of $0,20,40,60,80$ and $100 \mathrm{~kg} \mathrm{Pha}^{-1} \mathrm{yr}^{-1}$. Data are represented as mean \pm standard error. Fitted lines are based on linear regression models. The black and red lines represent without $\mathrm{N}$ and $\mathrm{N}$ addition, respectively. Significance was labeled for slopes of the black and red lines.

Table 3. Correlation analyses ( $R$ values) among soil inorganic fractions, Olsen-P, total phosphorus (TP) and organic $\mathrm{P}$ (TOP) with $\mathrm{Ca}\left(\mathrm{H}_{2} \mathrm{PO}_{4}\right)_{2}$ and $\mathrm{KH}_{2} \mathrm{PO}_{4}$ addition in the meadow steppe.

\begin{tabular}{|c|c|c|c|c|c|c|c|c|c|}
\hline & & $\mathrm{Fe}-\mathrm{P}$ & $\mathrm{Ca}_{2}-\mathrm{P}$ & $\mathrm{Ca}_{8}-\mathrm{P}$ & $\mathrm{Ca}_{10}-\mathrm{P}$ & $\mathrm{O}-\mathrm{P}$ & Olsen-P & $\mathrm{TP}$ & TOP \\
\hline $\begin{array}{l}\mathrm{KH}_{2} \mathrm{PO}_{4} \\
\text { addition }\end{array}$ & $\begin{array}{l}\mathrm{Al}-\mathrm{P} \\
\mathrm{Fe}-\mathrm{P} \\
\mathrm{Ca}_{2}-\mathrm{P} \\
\mathrm{Ca}_{8}-\mathrm{P} \\
\mathrm{Ca}_{10}-\mathrm{P} \\
\mathrm{O}-\mathrm{P} \\
\text { Olsen-P } \\
\text { TP }\end{array}$ & $0.92^{* *}$ & $\begin{array}{l}0.93^{* *} \\
0.95^{* *}\end{array}$ & $\begin{array}{l}0.87^{* *} \\
0.86^{* *} \\
0.92^{* *}\end{array}$ & $\begin{array}{r}0.25 \\
0.27^{*} \\
0.23 \\
0.29^{*}\end{array}$ & $\begin{array}{l}0.15 \\
0.19 \\
0.12 \\
0.10 \\
0.00\end{array}$ & $\begin{array}{r}0.70^{* *} \\
0.59^{* *} \\
0.63^{* *} \\
0.57^{* *} \\
0.17 \\
0.07\end{array}$ & $\begin{array}{r}0.44^{* *} \\
0.41^{* *} \\
0.41^{* *} \\
0.37^{* *} \\
0.06 \\
0.15 \\
0.52^{* *}\end{array}$ & $\begin{array}{r}-0.26^{*} \\
-0.28^{*} \\
-0.28^{*} \\
-0.29^{*} \\
-0.17 \\
0.01 \\
0.04 \\
0.74^{* *}\end{array}$ \\
\hline $\begin{array}{l}\mathrm{Ca}\left(\mathrm{H}_{2} \mathrm{PO}_{4}\right)_{2} \\
\text { addition }\end{array}$ & $\begin{array}{l}\mathrm{Al}-\mathrm{P} \\
\mathrm{Fe}-\mathrm{P} \\
\mathrm{Ca}_{2}-\mathrm{P} \\
\mathrm{Ca}_{8}-\mathrm{P} \\
\mathrm{Ca}_{10}-\mathrm{P} \\
\mathrm{O}-\mathrm{P} \\
\text { Olsen-P } \\
\text { TP }\end{array}$ & $0.91^{* *}$ & $\begin{array}{l}0.92^{* *} \\
0.94^{* *}\end{array}$ & $\begin{array}{l}0.80^{* *} \\
0.87^{* *} \\
0.84^{* *}\end{array}$ & $\begin{array}{r}0.47^{*} \\
0.49^{*} \\
0.42 \\
0.50^{*}\end{array}$ & $\begin{array}{r}-0.04 \\
-0.03 \\
-0.03 \\
0.05 \\
0.26^{*}\end{array}$ & $\begin{array}{r}0.48^{* *} \\
0.46^{* *} \\
0.53^{* *} \\
0.34^{* *} \\
0.11 \\
-0.29^{*}\end{array}$ & $\begin{array}{r}0.29^{*} \\
0.31^{*} \\
0.32^{*} \\
0.26^{* *} \\
0.17 \\
-0.03 \\
0.34^{*}\end{array}$ & $\begin{array}{r}-0.08 \\
0.01 \\
-0.06 \\
0.02 \\
-0.12 \\
-0.03 \\
0.14 \\
0.88^{* *}\end{array}$ \\
\hline
\end{tabular}

* Significance level at $0.05 .{ }^{* *}$ Significance level at 0.01 . 

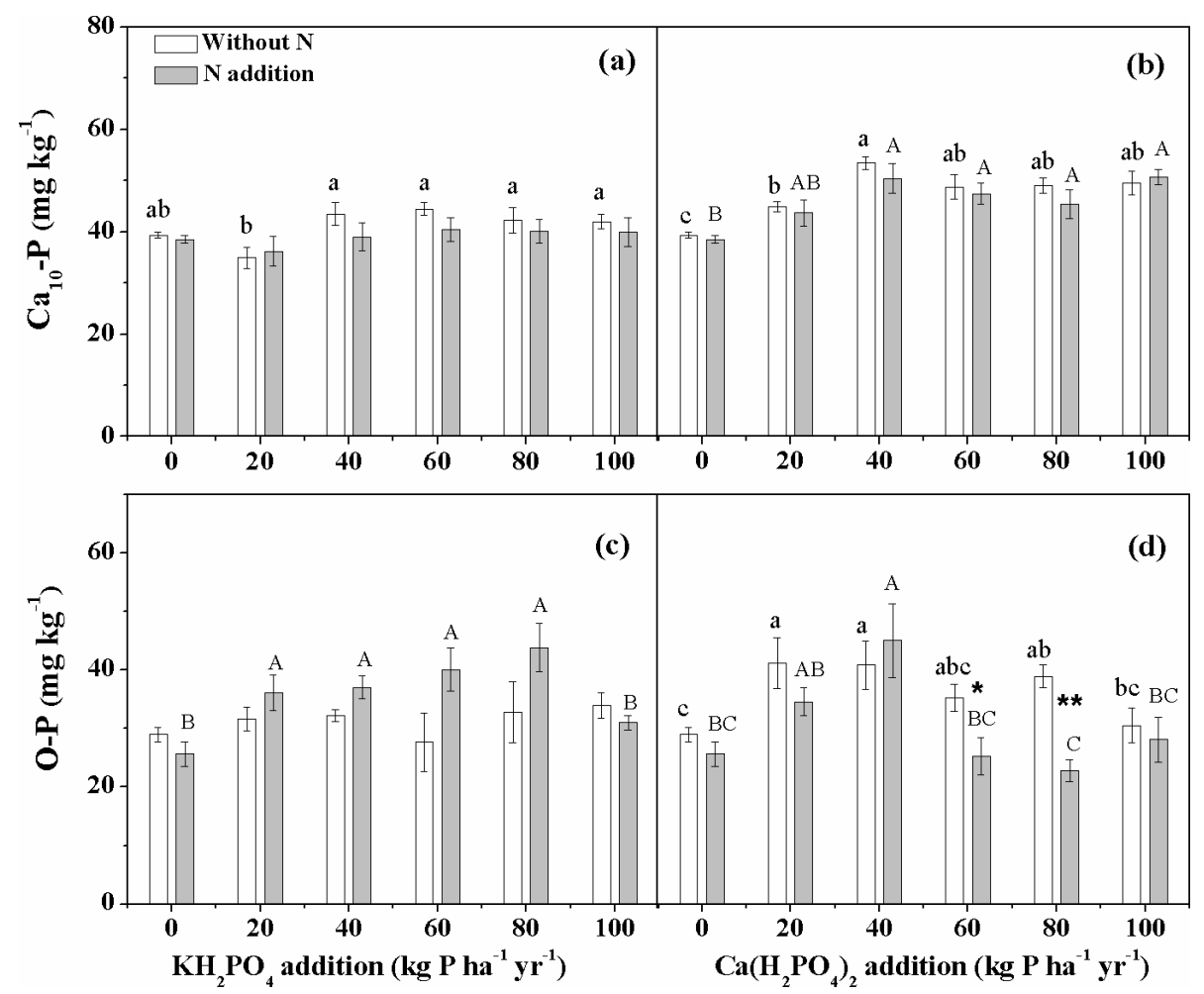

Figure 4. Effects of phosphorus $(\mathrm{P})$ and nitrogen $(\mathrm{N})$ additions on soil hydroxylapatite $\left(\mathrm{Ca}_{10}-\mathrm{P}\right)$ and occluded $\mathrm{P}(\mathrm{O}-\mathrm{P})$. Phosphorus types include $\mathrm{KH}_{2} \mathrm{PO}_{4}$ and $\mathrm{Ca}\left(\mathrm{H}_{2} \mathrm{PO}_{4}\right)_{2}$ at rates of $0,20,40,60,80$ and $100 \mathrm{~kg} \mathrm{Pha}^{-1} \mathrm{yr}^{-1}$. Data are represented as mean \pm standard error. Letters indicate significant differences between $\mathrm{P}$ rates of $\mathrm{KH}_{2} \mathrm{PO}_{4}$ or $\mathrm{Ca}\left(\mathrm{H}_{2} \mathrm{PO}_{4}\right)_{2}$ addition without $\mathrm{N}$ (lowercase letters) and with $\mathrm{N}$ addition (capital letters). Asterisks represent significance between $\mathrm{N}$ treatments within each $\mathrm{P}$ type and rate $\left(^{*}\right.$ and ${ }^{* *}$ for $P<0.05$ and 0.01 , respectively).

with a higher contribution for $\mathrm{KH}_{2} \mathrm{PO}_{4}$ addition (Fig. 6a, b). Soil moderate-cycling IP contributed to an increase in soil TP under both P compounds (Fig. 6a, b).

\section{Discussion}

\subsection{Effect of $P$ additions rates on soil IP fractions}

With increasing $\mathrm{P}$ addition levels, the increase in soil labile IP and moderate-cycling IP fractions was consistent with our first hypothesis and the findings from previous studies (Wang et al., 2010; Zhao et al., 2019). Soil IP fractions can be affected by nutrient addition, soil type and soil chemical properties (Daly et al., 2001; Stroia et al., 2011). The positive linear correlation of soil TIP concentration and $\mathrm{P}$ addition rates (Fig. S2) indicates that applied $\mathrm{P}$ was fixed mainly into inorganic forms (Chauhan et al., 1981) and converted to various soil P fractions (Piegholdt et al., 2013). Most of the applied $\mathrm{P}$ transformed into soil moderate-cycling IP fractions as seen from the decrease in the relative proportion of soil recalcitrant IP fractions (Fig. S1). Indeed, applied P fertilizer can be quickly bound by P-fixing constituents, e.g., $\mathrm{Fe}$ and $\mathrm{Al}$ oxides and clay minerals (Devau et al., 2011). In calcareous soils, precipitation is the main process retaining applied $\mathrm{P}$ in soils, especially precipitation with $\mathrm{Ca}$ at relatively high soil $\mathrm{pH}$ (Wang et al., 2010). Likely, the amount of P from input processes (exogenous $\mathrm{P}$ and weathering) was higher than the amount from output processes (plant uptake, erosion and leaching losses), which can eventually cause $\mathrm{P}$ accumulation in the soil as insoluble soil P fractions (Song et al., 2017). Therefore, both the monopotassium phosphate and monocalcium phosphate fertilizers transformed into soil labile IP and moderate-cycling IP fractions and contributed to the increase in soil Al-P, Fe-P, $\mathrm{Ca}_{2}-\mathrm{P}$ and $\mathrm{Ca}_{8}-\mathrm{P}$ concentrations (Fig. 7).

Inconsistent with our first hypothesis, we found significant changes in soil recalcitrant $\mathrm{P}$ fractions $\left(\mathrm{Ca}_{10}-\mathrm{P}\right.$ and $\left.\mathrm{O}-\mathrm{P}\right)$, which accounted for $21 \%-73 \%$ of soil TIP (Fig. S1) and potentially played an important role in supplying soil-available $\mathrm{P}$ in this meadow steppe (Fig. 7). The significant increase in soil $\mathrm{Ca}_{10}-\mathrm{P}$ with $\mathrm{Ca}\left(\mathrm{H}_{2} \mathrm{PO}_{4}\right)_{2}$ addition was not expected; and it was inconsistent with a previous study from a calcareous soil showing unchanged soil $\mathrm{Ca}_{10}-\mathrm{P}$ after 21 years of superphosphate application (Wang et al., 2010). In this calcareous soil, $\mathrm{Ca}\left(\mathrm{H}_{2} \mathrm{PO}_{4}\right)_{2}$ addition enhanced the transformation of soil $\mathrm{Ca}_{2}-\mathrm{P}$ and $\mathrm{Ca}_{8}-\mathrm{P}$ into more stable soil $\mathrm{Ca}_{10}-\mathrm{P}$ fractions for reasons that are not clear. In return, soil $\mathrm{Ca}_{10}-\mathrm{P}$ can be 


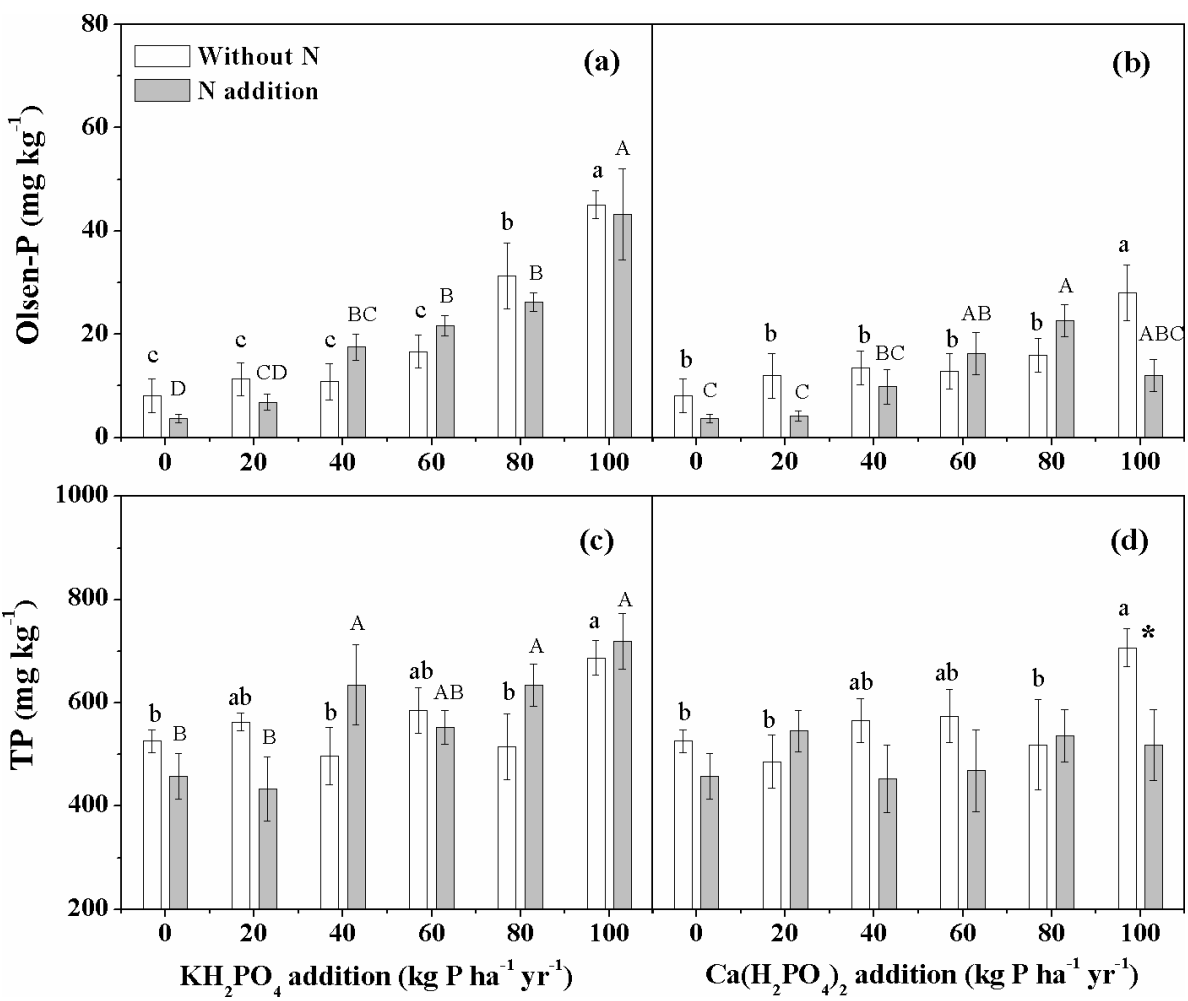

Figure 5. Effects of phosphorus $(\mathrm{P})$ and nitrogen $(\mathrm{N})$ additions on soil Olsen-P and total $\mathrm{P}(\mathrm{TP})$ in the meadow steppe. Phosphorus types include $\mathrm{KH}_{2} \mathrm{PO}_{4}$ and $\mathrm{Ca}\left(\mathrm{H}_{2} \mathrm{PO}_{4}\right)_{2}$ at rates of $0,20,40,60,80$ and $100 \mathrm{~kg} \mathrm{Pha}^{-1} \mathrm{yr}^{-1}$. Data are represented as mean \pm standard error. Letters indicate significant differences between $\mathrm{P}$ rates of $\mathrm{KH}_{2} \mathrm{PO}_{4}$ or $\mathrm{Ca}\left(\mathrm{H}_{2} \mathrm{PO}_{4}\right)_{2}$ addition without $\mathrm{N}$ (lowercase letters) and with $\mathrm{N}$ addition (capital letters). Asterisks represent significance between $\mathrm{N}$ treatments within each $\mathrm{P}$ type and rate $\left(^{*}\right.$ and ${ }^{* *}$ for $P<0.05$ and 0.01 , respectively).

a potential P sink of soil moderate-cycling IP pools because of its significant correlation with soil Fe-P under both chemical P forms (Table 3). Soil O-P showed a hump-shaped relationship with $\mathrm{P}$ addition for both $\mathrm{P}$ compounds when $\mathrm{N}$ was also supplied, while no relationship was found for $\mathrm{KH}_{2} \mathrm{PO}_{4}$ without $\mathrm{N}$ addition (Fig. 4c, d). This is in contrast to a 21 year long study where increased levels of $\mathrm{Ca}\left(\mathrm{H}_{2} \mathrm{PO}_{4}\right)_{2}$ significantly increased soil O-P (Wang et al., 2010). The discrepancy might be due to (1) differences in soil type affecting soil P dynamics differently (a Calcarid Regosol in the Wang et al., 2010, study and a Chernozem in this study); (2) different $\mathrm{P}$ compounds having different effects on soil O$\mathrm{P}$ cycling; (3) $\mathrm{N}$ addition interacting with $\mathrm{P}$ to affect plant $\mathrm{P}$ uptake and soil O-P transformations (Marklein and Houlton, 2012; Zhang et al., 2004). Thus, $\mathrm{P}$ addition effects on soil O-P and other soil recalcitrant $\mathrm{P}$ fractions were complex, particularly when $\mathrm{N}$ was also added.

The significant increase in soil Olsen-P with $\mathrm{P}$ addition levels was consistent with previous studies (Karaca et al., 2002; Zhou et al., 2018). Significant increase in soil Olsen$\mathrm{P}$ most likely was a consequence of inputs of $\mathrm{P}$ going into this pool surpassing output processes of mineral fixation, leaching and plant uptake. Dissolution of exogenous P com- pounds could be the primary input process, which then directly contributed to the increase in soil Olsen-P concentration. Moreover, the soil IP pools, especially soil Fe-P, Al-P, $\mathrm{Ca}_{2}-\mathrm{P}$ and $\mathrm{Ca}_{8}-\mathrm{P}$, can also be an important source of bioavailable P (Zhang et al., 2012). Significantly positive correlations between soil moderate-cycling IP fractions and soil labile IP (Table 3; Fig. 6) suggest that soil moderate-cycling IP fractions contributed strongly to enhance soil $\mathrm{P}$ availability (Fig. 7). Indeed, soil moderate-cycling IP fractions could release soil-available $\mathrm{P}$ more easily than recalcitrant IP fractions (Zhang et al., 2012).

\subsection{Effects of compound-specific $P$ additions}

Consistent with our second hypothesis, soil labile IP and moderate-cycling IP fractions of $\mathrm{Al}-\mathrm{P}, \mathrm{Fe}-\mathrm{P}$ and $\mathrm{Ca}_{8}-\mathrm{P}$ tended to be higher with soluble $\mathrm{KH}_{2} \mathrm{PO}_{4}$ addition than with less soluble $\mathrm{Ca}\left(\mathrm{H}_{2} \mathrm{PO}_{4}\right)_{2}$ addition with significant increases in some $\mathrm{P}$ addition levels (Figs. 2 and 3). Compared to $\mathrm{Ca}\left(\mathrm{H}_{2} \mathrm{PO}_{4}\right)_{2}, \mathrm{KH}_{2} \mathrm{PO}_{4}$ is more effective in elevating soil phosphate levels to form soil labile IP and moderate-cycling IP fractions by rapidly interacting with $\mathrm{Fe}$ - and $\mathrm{Al}$-oxides and $\mathrm{CaCO}_{3}$ (Havlin et al., 2005). The decrease in soil $\mathrm{pH}$ contributed to the increase in labile IP with $\mathrm{Ca}\left(\mathrm{H}_{2} \mathrm{PO}_{4}\right)_{2}$ addi- 
(a) $\mathrm{KH}_{2} \mathrm{PO}_{4}$

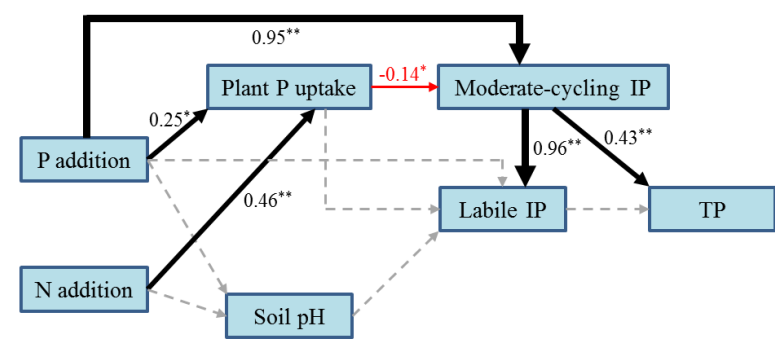

(b) $\mathrm{Ca}\left(\mathrm{H}_{2} \mathrm{PO}_{4}\right)$

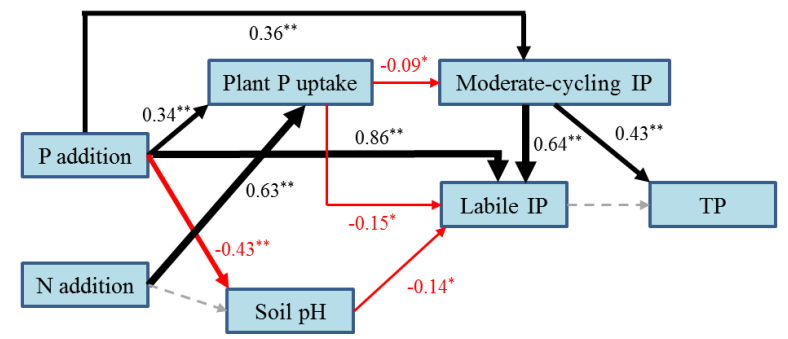

Figure 6. Structural equation model of the relationships between soil $\mathrm{pH}$, plant $\mathrm{P}$ uptake, soil moderate-cycling inorganic phosphorus (IP), labile $\mathrm{P}$, and TP under $\mathrm{KH}_{2} \mathrm{PO}_{4}\left(\mathbf{a}, \chi^{2}=23.44, P=0.38\right.$, $\mathrm{RMSEA}=0.03, \mathrm{AIC}=67.44)$ and $\mathrm{Ca}\left(\mathrm{H}_{2} \mathrm{PO}_{4}\right)_{2}$ additions $\left(\mathbf{b}, \chi^{2}=\right.$ 27.01, $P=0.08$, RMSEA $=0.09$, AIC $=79.01)$ across $\mathrm{N}$ treatments. Arrows indicate positive (black), negative (red) and neutral (dotted grey) effects. Arrow width is proportional to the strength of the relationship. The number adjacent to each arrow is the standardized path coefficient with corresponding significance $(* * *$ for $P<0.05$ and 0.01 , respectively)

tion (Fig. 6b). Lower soil $\mathrm{pH}$ could accelerate soil recalcitrant IP fractions converting into soil labile IP, moderate-cycling IP and Olsen-P (Alt et al., 2013). Under the $\mathrm{Ca}\left(\mathrm{H}_{2} \mathrm{PO}_{4}\right)_{2}$ treatment, significant negative relationships of soil O-P and Olsen-P further support this argument (Table 3 ). On the other hand, plant $\mathrm{P}$ uptake instead of soil $\mathrm{pH}$ was more responsible for variations in soil moderate-cycling IP fractions with $\mathrm{KH}_{2} \mathrm{PO}_{4}$ addition (Fig. 6a). Under both $\mathrm{P}$ compounds, soil moderate-cycling IP fractions contributed to an increase in soil labile IP across $\mathrm{N}$ treatments (Fig. 6), which suggested that higher plant growth and P demand (Fig. 1c, d) could enhance the conversion of soil moderate-cycling IP fraction into labile or available $\mathrm{P}$.

In contrast to our expectation, soil recalcitrant IP fractions of O-P and $\mathrm{Ca}_{10}-\mathrm{P}$ were higher with $\mathrm{Ca}\left(\mathrm{H}_{2} \mathrm{PO}_{4}\right)_{2}$ than with $\mathrm{KH}_{2} \mathrm{PO}_{4}$ addition (Figs. 4 and 7). This suggests that a higher proportion of $\mathrm{Ca}\left(\mathrm{H}_{2} \mathrm{PO}_{4}\right)_{2}$ was converted into stable inorganic $\mathrm{P}$ forms than the more soluble $\mathrm{KH}_{2} \mathrm{PO}_{4}$. Additionally, lower soil O-P and $\mathrm{Ca}_{10}-\mathrm{P}$ concentrations could be caused by enhanced plant $\mathrm{P}$ uptake intensity under $\mathrm{KH}_{2} \mathrm{PO}_{4}$ addition, which facilitated more soil recalcitrant IP fractions transforming into moderate-cycling IP and labile IP. Thus, $\mathrm{Ca}\left(\mathrm{H}_{2} \mathrm{PO}_{4}\right)_{2}$ appears to be better than the $\mathrm{KH}_{2} \mathrm{PO}_{4}$ at main-

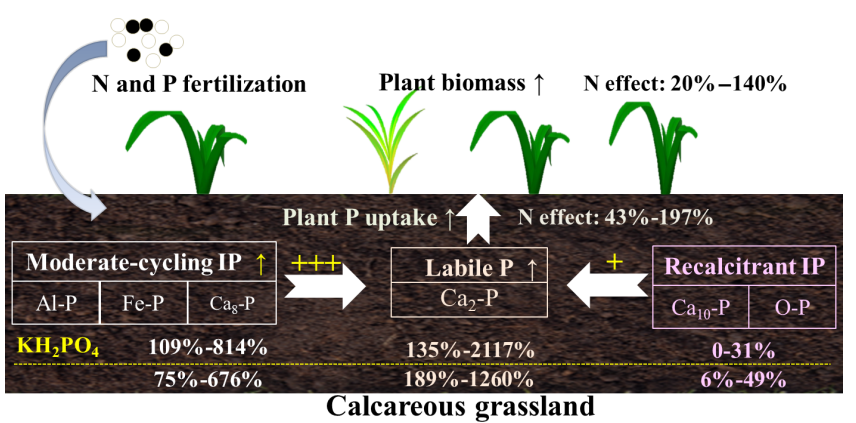

Figure 7. Schematic diagram shows the effects of phosphorus $(\mathrm{P})$ compound addition on soil inorganic $\mathrm{P}$ transformations in the calcareous grassland of Inner Mongolia. The percentages represent increase ("个" in the diagram) of soil inorganic $\mathrm{P}$ fractions, plant $\mathrm{P}$ uptake and plant biomass as affected by fertilization across $\mathrm{P}$ addition rates. $\mathrm{KH}_{2} \mathrm{PO}_{4}$ addition had a larger impact on moderate-cycling IP (sum of Al-P, Fe-P and $\mathrm{Ca}_{8}-\mathrm{P}$ ) as compared to $\mathrm{Ca}\left(\mathrm{H}_{2} \mathrm{PO}_{4}\right)_{2}$ (109\%-814\% vs. $75 \%-676 \%$ ). However, recalcitrant $\mathrm{P}$ (sum of $\mathrm{Ca}_{10}-\mathrm{P}$ and $\left.\mathrm{O}-\mathrm{P}\right)$ increased more with $\mathrm{Ca}\left(\mathrm{H}_{2} \mathrm{PO}_{4}\right)_{2}$ addition relative to $\mathrm{KH}_{2} \mathrm{PO}_{4}(6 \%-49 \%$ vs. $0 \%-31 \%)$. Nitrogen addition decreased moderate-cycling $\mathrm{P}$ by enhancing plant biomass and plant $\mathrm{P}$ uptake for both $\mathrm{P}$ compound additions across $\mathrm{P}$ addition rates. Therefore, moderate-cycling $\mathrm{P}$ showed a higher contribution to soil labile $\mathrm{P}$ than recalcitrant $\mathrm{P}$, as represented by " +++ " and " + ", respectively.

taining soil recalcitrant IP fractions in the grassland soil. Although soil recalcitrant IP fractions (O-P and $\left.\mathrm{Ca}_{10}-\mathrm{P}\right)$ are relatively stable, they play essential roles in buffering the depletion of soil moderate-cycling $\mathrm{P}$ and maintaining soilavailable P levels (Seeling and Jungk, 1996; Vu et al., 2008).

As expected, more soluble $\mathrm{KH}_{2} \mathrm{PO}_{4}$ could result in higher labile IP (Fig. 7) in soil solution through dissolution. It is generally observed that this more soluble $\mathrm{P}$ fertilizer type dissolves in soil water over a shorter time period and generates more free $\mathrm{PO}_{4}^{3-}$ (Chien et al., 2011). Soil moderatecycling IP fractions also contributed to elevated soil Olsen-P concentrations with stronger correlations under $\mathrm{KH}_{2} \mathrm{PO}_{4}$ addition (Table 3). Soil moderate-cycling IP factions showed a stronger direct and positive effect on soil labile IP with $\mathrm{KH}_{2} \mathrm{PO}_{4}$ addition than $\mathrm{Ca}\left(\mathrm{H}_{2} \mathrm{PO}_{4}\right)_{2}$ addition, while plant $\mathrm{P}$ uptake showed both indirect negative (by negatively affecting soil moderate-cycling IP) and direct negative effects on labile IP with $\mathrm{Ca}\left(\mathrm{H}_{2} \mathrm{PO}_{4}\right)_{2}$ addition (Fig. 6). Based on the correlation analyses between soil IP fractions and Olsen-P, we found that soil $\mathrm{Ca}_{2}-\mathrm{P}$ and $\mathrm{Al}-\mathrm{P}$ were the dominant soil IP fractions to improve soil $\mathrm{P}$ availability in the calcareous soil. Our results suggest that $\mathrm{KH}_{2} \mathrm{PO}_{4}$ was better than $\mathrm{Ca}\left(\mathrm{H}_{2} \mathrm{PO}_{4}\right)_{2}$ at alleviating $\mathrm{P}$ limitations of soil microorganisms and plants by promoting the formation of soil labile IP and moderatecycling IP fractions in the meadow steppe. 


\subsection{Nitrogen-addition-regulated $P$ effects on soil inorganic $\mathbf{P}$ fractions}

We predicted that the concentrations of soil IP fractions would be lower under combined $\mathrm{P}$ and $\mathrm{N}$ additions than under $\mathrm{P}$ addition alone because of increased plant $\mathrm{P}$ uptake with $\mathrm{N}$ addition (third hypothesis). We found some support for this, where combined $\mathrm{P}$ and $\mathrm{N}$ additions decreased most soil IP fractions compared to $\mathrm{P}$ addition alone, except for the soil $\mathrm{Ca}_{10}-\mathrm{P}$ fraction. We also found a significant increase in plant biomass with combined $\mathrm{P}$ and $\mathrm{N}$ addition (Fig. 1a, b) and a negative correlation between plant $\mathrm{P}$ uptake and moderate-cycling IP fractions (Fig. 6a, b). Therefore, the decrease in soil moderate-cycling IP fractions with $\mathrm{N}$ addition could have been due to enhanced plant P uptake (Fig. 1c, d) as a result of increased plant biomass (Figs. 1a, b and 7). Under $\mathrm{N}$ addition, simultaneous increases in soil Olsen$\mathrm{P}$ output (plant uptake) and input pathways (transformation from soil moderate-cycling IP fractions) may have resulted in mostly nonsignificant difference in soil Olsen-P concentrations between combined $\mathrm{P}$ and $\mathrm{N}$ addition and $\mathrm{P}$ addition alone (Fig. 5a, b). Nitrogen addition can potentially increase soil $\mathrm{P}$ availability by promoting solubilization of soil IP fractions in the short term (Wang et al., 2016). However, long-term $\mathrm{N}$ deposition resulted in soil IP-exhaustion, thereby constraining the growth of plants (Olander and Vitousek, 2000; Yang et al., 2014). Previous research has also found that decades of $\mathrm{N}$ addition could accelerate $\mathrm{PO}_{4}^{3-}$ release (Malik et al., 2012; Stroia et al., 2011) and enhance conversion of soil recalcitrant IP fractions to soil labile IP and moderate-cycling IP fractions as a result of soil acidification (Alt et al., 2013). Additionally, $\mathrm{N}$ addition was found to suppress acid and alkaline phosphatase enzymes, resulting in a decrease in soil organic $\mathrm{P}$ mineralization in a similar semiarid grassland (Tian et al., 2016). Therefore, combined $\mathrm{N}$ and $\mathrm{P}$ addition might decrease soil IP fractions by reducing the conversion of soil organic $\mathrm{P}$ to IP as compared to $\mathrm{P}$ addition alone. Our results clearly illustrate that $\mathrm{N}$ effects on soil IP fractions depended on P inputs, where combined N and $\mathrm{P}$ additions could accelerate conversion of soil moderatecycling IP fractions into soil-available $\mathrm{P}$ and enhance plant $\mathrm{P}$ uptake and biomass (Fig. 7).

\section{Conclusions}

Addition of $\mathrm{P}$ compounds significantly increased soil moderate-cycling IP fractions of Al-P, Fe-P, $\mathrm{Ca}_{2}-\mathrm{P}$ and $\mathrm{Ca}_{8}-$ $\mathrm{P}$, which may have contributed to higher available $\mathrm{P}$ (Olsen$\mathrm{P})$ in the soil. Soil moderate-cycling IP fractions were higher with soluble $\mathrm{KH}_{2} \mathrm{PO}_{4}$ addition, but, in contrast, soil recalcitrant fractions of $\mathrm{Ca}_{10}-\mathrm{P}$ and $\mathrm{O}-\mathrm{P}$ were higher with $\mathrm{Ca}\left(\mathrm{H}_{2} \mathrm{PO}_{4}\right)_{2}$ addition. Combined $\mathrm{N}$ and $\mathrm{P}$ addition decreased soil IP fractions due to enhanced plant $\mathrm{P}$ uptake compared to $\mathrm{P}$ addition alone for both $\mathrm{P}$ compounds. Thus, $\mathrm{N}$ addition pro- moted the transformation of soil moderate and recalcitrant IP fractions into available forms. Soil moderate-cycling IP fractions had a greater contribution to soil $\mathrm{P}$ availability than soil recalcitrant $\mathrm{P}$ fractions. Our findings elucidated the interactive effects of $\mathrm{N}$ and $\mathrm{P}$ addition on soil IP dynamics and presented the first evidence for the relative roles of exogenous $\mathrm{P}$ compounds in regulating $\mathrm{P}$ availability in the meadow steppe grassland. Overall, $\mathrm{P}$ fertilization is necessary for promoting productivity and sustainable management of grasslands by maintaining soil $\mathrm{P}$ availability and pools under scenarios of ecosystem $\mathrm{N}$ enrichment.

Data availability. The datasets used and/or analyzed in the present study are available from the corresponding author on reasonable request.

Supplement. The supplement related to this article is available online at: https://doi.org/10.5194/bg-16-4293-2019-supplement.

Author contributions. ZW and YJ designed the study. HL, HW and ZS performed samplings of soils and plants. HL completed laboratory analyses. RW and FAD contributed to the interpretation and discussion of the results. HL prepared the manuscript with suggestions from all the co-authors.

Competing interests. The authors declare that they have no conflict of interest.

Acknowledgements. We acknowledge the Erguna Forest-Steppe Ecotone Ecosystem Research Station, Institute of Applied Ecology, Chinese Academy of Sciences, for logistical support.

Financial support. This research has been supported by the National Natural Science Foundation of China (grant nos. 31770525 and 31870441), the National Key Research and Development Program of China (grant no. 2016YFC0500707), and the Youth Innovation Promotion Association CAS (grant no. Y9QCH121YY).

Review statement. This paper was edited by Nobuhito Ohte and reviewed by two anonymous referees.

\section{References}

Al-Khateeb, I. K., Raihan, M. J., and Asker, S. R.: Phase equilibrium and kinetics of orthophosphate in some Iraqi soils, Soil Sci., 141, 31-37, https://doi.org/10.1097/00010694-19860100000006, 1986.

Alt, F., Oelmann, Y., Schöning, I., and Wilcke, W.: Phosphate release kinetics in calcareous grassland and forest soils in re- 
sponse to $\mathrm{H}^{+}$addition, Soil Sci. Soc. Am. J., 77, 2060-2070, https://doi.org/10.2136/sssaj2013.02.0072, 2013.

Baumann, K., Glaser, K., Mutz, J., Karsten, U., MacLennan, A., Hu, Y. F., Michalik, D., Kruse, J., Eckhardt, K. U., Schall, P., and Leinweber, P.: Biological soil crusts of temperate forests: Their role in P cycling, Soil Biol. Biochem., 109, 156-166, https://doi.org/10.1016/j.soilbio.2017.02.011, 2017.

Cao, N., Chen, X., Cui, Z., and Zhang, F.: Change in soil available phosphorus in relation to the phosphorus budget in China, Nutr. Cycl. Agroecosys., 94, 161-170, https://doi.org/10.1007/s10705-012-9530-0, 2012.

Chang, S. C. and Jackson, M. L.: Soil phosphorus fractions in some representative soils, Eur. J. Soil Sci., 84, 133-144, https://doi.org/10.1111/j.1365-2389.1958.tb01903.x, 1958.

Chauhan, B. S., Stewart, J. W. B., and Paul, E. A.: Effect of labile inorganic phosphorus status and organic carbon additions on the microbial uptake of phosphorus in soils, Can. J. Soil Sci., 61, 373-385, https://doi.org/10.4141/cjss81-041, 1981.

Chen, C. L. M., Condron, M. R., and Davis, S. R. R.: Phosphorus dynamics in the rhizosphere of perennial ryegrass (Lolium perenne L.) and radiata pine (Pinus radiata D. Don.), Soil Biol. Biochem., 34, 487-499, https://doi.org/10.1016/S00380717(01)00207-3, 2002.

Chien, S. H., Prochnow, L. I., Tu, S., and Snyder, C. S.: Agronomic and environmental aspects of phosphate fertilizers varying in source and solubility: an update review, Nutr. Cycl. Agroecosys., 89, 229-255, https://doi.org/10.1007/s10705-010-9390-4, 2011.

Condron, L. M., and Goh, K. M.: Effects of long-term phosphatic fertilizer applications on amounts and forms of phosphorus in soils under irrigated pasture in New Zealand, J. Soil Sci., 40, 383-395, https://doi.org/10.1111/j.13652389.1989.tb01282.x, 1989.

Crowley, K. F., Mcneil, B. E., Lovett, G. M., Canham, C. D., Driscoll, C. T., Rustad, L. E., Denny, E., Hallett, R. A., Arthur, M. A., Boggs, J. L., Goodale, C. L., Kahl, J. S., McNulty, S. G., Olliinger, S. V., Pardo, L. H., Schaberg, P. G., Stoddard, J. L., Weand, M. P., and Weathers, K. C.: Do nutrient limitation patterns shift from nitrogen toward phosphorus with increasing nitrogen deposition across the Northeastern United States?, Ecosystems, 15, 940-957, https://doi.org/10.1007/s10021-0129550-2, 2012.

Daly, K., Jeffrey, D., and Tunney, H.: The effect of soil type on phosphorus sorption capacity and desorption dynamiacs in Irish grassland soils, Soil Use Manag., 17, 12-20, https://doi.org/10.1111/j.1475-2743.2001.tb00003.x, 2001.

Devau, N., Hinsinger, P., Le Cadre, E., and Gérard, F.: Rootinduced processes controlling phosphate availability in soils with contrasted P-fertilized treatments, Plant Soil, 348, 203-218, https://doi.org/10.1007/s11104-011-0935-3, 2011.

Feng, J., Turner, B. L., Lü, X., Chen, Z., Wei, K., Tian, J., Wang, C., Luo, W., and Chen, L.: Phosphorus transformations along a large-scale climosequence in arid and semiarid grasslands of northern China, Global Biogeochem. Cy., 30, 1264-1275, https://doi.org/10.1002/2015GB005331, 2016.

Gong, X., Chen, Q., Dittert, K., Taube, F., and Lin, S.: Nitrogen, phosphorus and potassium nutritional status of semiarid steppe grassland in Inner Mongolia, Plant Soil, 340, 265-278, https://doi.org/10.1007/s11104-010-0577-x, 2011.
Güsewell, S.: $\mathrm{N}: \mathrm{P}$ ratios in terrestrial plants: variation and functional significance, New Phytol., 164, 243-266, https://doi.org/10.1111/j.1469-8137.2004.01192.x, 2004.

Gustafsson, J. P., Mwamila, L. B., and Kergoat, K.: The $\mathrm{pH}$ dependence of phosphate sorption and desorption in Swedish agricultural soils, Geoderma, 189, 304-311, https://doi.org/10.1016/j.geoderma.2012.05.014, 2012.

Halajnia, A., Haghnia, G. H., Fotovat, A., and Khorasani, R.: Phosphorus fractions in calcareous soils amended with $\mathrm{P}$ fertilizer and cattle manure, Geoderma, 150, 0-213, https://doi.org/10.1016/j.geoderma.2009.02.010, 2009.

Havlin, J. L., Beaton, J. D., Tisdale, S. L., and Nelson, W. L.: Soil Fertility and Fertilizers: An Introduction to Nutrient Management, 7th Edn., Prentice Hall, New Jersey, 2005.

Herlihy, M. and Mcgrath, D.: Phosphorus fractions and adsorption characteristics in grassland soils of varied soil phosphorus status, Nutr. Cycl. Agroecosys., 77, 15-27, https://doi.org/10.1007/s10705-006-6687-4, 2006.

Hinsinger, P.: Bioavailability of soil inorganic $\mathrm{P}$ in the rhizosphere as affected by root-induced chemical changes: a review, Plant Soil, 237, 173-195, https://doi.org/10.1023/A:1013351617532, 2001.

Hogan, E. J., Minnullina, G., Sheppard, L. J., Leith, I. D., and Crittenden, P. D.: Response of phosphomonoesterase activity in the lichen Cladonia portentosa to nitrogen and phosphorus enrichment in a field manipulation experiment, New Phytol., 186, 926933, https://doi.org/10.1111/j.1469-8137.2010.03221.x, 2010.

IUSS Working Group WRB: World Reference Base for Soil Resources 2014. International soil classification system for naming soils and creating legends for soil maps, World Soil Resources Reports No. 106, FAO, Rome, 2014.

Jiang, B. and Gu, Y.: A suggested fractionation scheme of inorganic phosphorus in calcareous soils, Fert. Res., 20, 159-165, https://doi.org/10.1007/BF01054551, 1989.

Kang, L., Han, X., Zhang, Z., and Sun, O. J.: Grassland ecosystems in China: review of current knowledge and research advancement, Philos. T. R. Soc. B, 362, 997-1008, https://doi.org/10.1098/rstb.2007.2029, 2007.

Karaca, A., Naseby, D., and Lynch, J.: Effect of cadmium contamination with sewage sludge and phosphate fertiliser amendments on soil enzyme activities, microbial structure and available cadmium, Biol. Fert. Soils, 35, 428-434, https://doi.org/10.1007/s00374-002-0490-4, 2002.

Luo, W., Elser, J. J., Lü, X., Wang, Z., Bai, E., Yan, C., Wang, C., Li, M., Zimmermann, N. E., Han, X., Li, H., Wu, Y., and Jiang, Y.: Plant nutrients do not covary with soil nutrients under changing climatic conditions, Global Biogeochem. Cy., 29, 1298-1308, https://doi.org/10.1002/2015GB005089, 2015.

Maistry, P. M., Muasya, A. M., Valentine, A. J., and Chimphango, S. B. M.: Increasing nitrogen supply stimulates phosphorus acquisition mechanisms in the fynbos species Aspalathus linearis, Funct. Plant Biol., 42, 52-62, do:10.1071/FP14100, 2015.

Malik, M. A., Marschner, P., and Khan, K. S.: Addition of organic and inorganic $\mathrm{P}$ sources to soil - Effects on $\mathrm{P}$ pools and microorganisms, Soil Biol. Biochem., 49, 106-113, https://doi.org/10.1016/j.soilbio.2012.02.013, 2012.

Margenot, A. J., Sommer, R., Mukalama, J., and Parikh, S. J.: Biological $P$ cycling is influenced by the form of 
$\mathrm{P}$ fertilizer in an Oxisol, Biol. Fert. Soils, 53, 899-909, https://doi.org/10.1007/s00374-017-1226-9, 2017.

Marklein, A. R. and Houlton, B. Z.: Nitrogen inputs accelerate phosphorus cycling rates across a wide variety of terrestrial ecosystems, New Phytol., 193, 696-704, https://doi.org/10.1111/j.1469-8137.2011.03967.x, 2012.

Meena, M. D., Narjary, B., Sheoran, P. Jat, H. S., Joshi, P. K., Chinchmalatpure, A. R., Yadav, G. M., Yadav, R. K., and Meena, M. K.: Changes of phosphorus fractions in saline soil amended with municipal solid waste compost and mineral fertilizers in a mustard-pearl millet cropping system, Catena, 160, 32-40, https://doi.org/10.1016/j.catena.2017.09.002, 2018.

Mortvedt, J. J., Follett, R. H. C., and Murphy, L. S. C.: Fertilizer technology and application, Meister Publishing Company, Willoughby, OH, 1999.

Murphy, J. and Riley, J. P.: A modified single solution method for determination of phosphate in natural waters, Anal. Chim. Acta, 27, 3-36, https://doi.org/10.1016/S0003-2670(00)88444$5,1962$.

Nguyen, M. L., Rickard, S. D., and Mcbride, S. D.: Pasture production and changes in phosphorus and sulphur status in irrigated pastures receiving long-term applications of superphosphate fertilizer, New Zeal. J. Agr. Res., 32, 245-262, https://doi.org/10.1080/00288233.1989.10423460, 2012.

Olander, L. P. and Vitousek, P. M.: Regulation of soil phosphatase and chitinase activity by $\mathrm{N}$ and $\mathrm{P}$ availability, Biogeochemistry, 49, 175-190, https://doi.org/10.1023/A:1006316117817, 2000.

Olsen, S. R., Cole, C. V., Watanabe, F. S., and Dean, L. A.: Estimation of available phosphorus in soils by extraction with sodium bicarbonate, USDA circular 939, U.S. Govt. Printing Office, Washington, DC, 1954.

Piegholdt, C., Geisseler, D., Koch, H., and Ludwig, B.: Longterm tillage effects on the distribution of phosphorus fractions of loess soils in Germany, J. Plant Nutr. Soil Sci., 176, 217-226, https://doi.org/10.1002/jpln.201200393, 2013.

Ross, D. J., Speir, T. W., and Kettle, H. A.: Soil: microbial biomass, $\mathrm{C}$ and $\mathrm{N}$ mineralization and enzyme activities in a hill pasture: influence of season and slow-release $\mathrm{P}$ and $\mathrm{S}$ fertilizer, Soil Biol. Biochem., 27, 1431-1443, https://doi.org/10.1016/00380717(95)00069-Q, 1995.

Sah, R. N., Mikkelsen, D. S., and Hafez, A. A.: Phosphorus behavior in flooded-drained soils. II. Iron transformation and phosphorus sorption, Soil Sci. Soc. Am. J., 53, 1723-1729, https://doi.org/10.2136/sssaj1989.03615995005300060019x, 1989.

Schrijver, A. D., Vesterdal, L., Hansen, K., Frenne, P. D., Augusto, L., Achat, D. L., Staelens, J., Baeten, L., Keermaeker, L. D., Neve, S. D., and Verheyen, K.: Four decades of postagricultural forest development have caused major redistributions of soil phosphorus fractions, Oecologia, 169, 221-234, https://doi.org/10.1007/s00442-011-2185-8, 2012.

Seeling, B. and Jungk, A.: Utilization of organic phosphorus in calcium chloride extracts of soil by barley plants and hydrolysis by acid and alkaline phosphatases, Plant Soil, 178, 179-184, https://doi.org/10.1007/BF00011581, 1996.

Shen, J., Li, R., Zhang, F., Fan, J., Tang, C., and Rengel, Z.: Crop yields, soil fertility and phosphorus fractions in response to long-term fertilization under the rice monoculture system on a calcareous soil, Field Crops Res., 86, 225-238, https://doi.org/10.1016/j.fcr.2003.08.013, 2004

Shuman, L. M.: Effect of phosphorus level on extractable micronutrients and their distribution among soil fractions, Soil Sci. Soc. Am. J., 52, 136-141, https://doi.org/10.2136/sssaj1988.03615995005200010024x, 1988.

Sigua, G. C., Stone, K. C., Bauer, P. J., and Szogi, A. A.: Phosphorus dynamics and phosphatase activity of soils under corn production with supplemental irrigation in humid coastal plain region, USA, Nutr. Cycl. Agroecosys., 109, 249-267, https://doi.org/10.1007/s10705-017-9882-6, 2017.

Sommers, L. E. and Nelson, D. W.: Determination of total phosphorus in soils: a rapid perchloric acid digestion procedure, Soil Sci. Soc. Am. J., 36, 902-904, https://doi.org/10.2136/sssaj1972.03615995003600060020x, 1972.

Song, K., Xue, Y., Zheng, X., Lv, W., Qiao, H., Qin, Q., and Yang, J.: Effects of the continuous use of organic manure and chemical fertilizer on soil inorganic phosphorus fractions in calcareous soil, Sci. Rep.-UK, 7, 1164, https://doi.org/10.1038/s41598-01701232-2, 2017.

Stroia, C., Morel, C., and Jouany, C.: Nitrogen fertilization effects on grassland soil acidification: consequences on diffusive phosphorus ions, Soil Sci. Soc. Am. J., 75, 112-120, https://doi.org/10.2136/sssaj2009.0135, 2011.

Sun, X., Shen, Y., Schuster, M. J., Searle, E. B., Chen, J., Yang, G., and Zhang, Y.: Initial responses of grass litter tissue chemistry and $\mathrm{N}: \mathrm{P}$ stoichiometry to varied $\mathrm{N}$ and $\mathrm{P}$ input rates and ratios in Inner Mongolia, Agr. Ecosyst. Environ., 252, 114-125, https://doi.org/10.1016/j.agee.2017.10.007, 2018.

Tang, X., Ma, Y., Hao, X., Li, X., Li, J., Huang, S., and Yang, X.: Determining critical values of soil Olsen-P for maize and winter wheat from long-term experiments in China, Plant Soil, 323 143-151, https://doi.org/10.1007/s11104-009-9919-y, 2009.

Thomas, R. L., Sheard, R. W., and Moyer, J. R.: Comparison of conventional and automated procedures for nitrogen, phosphorus, and potassium analysis of plant material using a single digestion, Agron. J., 59, 240-243, https://doi.org/10.2134/agronj1967.00021962005900030010x, 1967.

Tian, J., Wei, K., Condron, L. M., Chen, Z., Xu, Z., and Chen, L.: Impact of land use and nutrient addition on phosphatase activitities and their relationships with organic phosphorus turnover in semi-arid grassland soils, Biol. Fert. Soils, 52, 675-683, https://doi.org/10.1007/s00374-016-1110-z, 2016.

Vitousek, P. M., Porder, S., Houlton, B. Z., and Chadwick, O. A.: Terrestrial phosphorus limitation: mechanism, implications, and nitrogen-phosphorus interactions, Ecol. Appl., 20, 5-15, https://doi.org/10.1890/08-0127.1, 2010.

Vu, D. T., Tang, C., and Armstrong, R. D.: Changes and availability of $\mathrm{P}$ fractions following 65 years of $\mathrm{P}$ application to a calcareous soil in a Mediterranean climate, Plant Soil, 304, 21-33, https://doi.org/10.1007/s11104-007-9516-x, 2008.

Walker, T. W. and Syers, J. K.: The fate of phosphorus during pedogenesis, Geoderma, 15, 1-19, https://doi.org/10.1016/00167061(76)90066-5, 1976.

Wang, J., Liu, W., Mu, H., and Dang, T.: Inorganic phosphorus fractions and phosphorus availability in a calcareous soil receiving 
21-year superphosphate application, Pedosphere, 20, 304-310, https://doi.org/10.1016/S1002-0160(10)60018-5, 2010.

Wang, R., Creamer, C. A., Wang, X., He, P., Xu, Z., and Jiang, Y.: The effects of a 9-year nitrogen and water addition on soil aggregate phosphorus and sulfur availability in a semi-arid grassland, Ecol. Indic., 61, 806-814, https://doi.org/10.1016/j.ecolind.2015.10.033, 2016.

Xiong, L., Wang, P., and Kopittke, P. M.: Tailoring hydroxyapatite nanoparticles to increase their efficiency as phosphorus fertilisers in soils, Geoderma, 323, 116-125, https://doi.org/10.1016/j.geoderma.2018.03.002, 2018.

Yang, K., Zhu, J., Gu, J., Yu, L., and Wang, Z.: Changes in soil phosphorus fractions after 9 years of continuous nitrogen addition in a Larix gmelinii plantation, Ann. Forest Sci., 72, 435-442, https://doi.org/10.1007/s13595-014-0444-7, 2014.

Zhang, B., Fang, F., Guo, J., Chen, Y., Li, Z., and Guo, S.: Phosphorus fractions and phosphate sorption-release characteristics relevant to the soil composition of water-level-fluctuating zone of Three Gorges Reservoir, Ecol. Eng., 40, 153-159, https://doi.org/10.1016/j.ecoleng.2011.12.024, 2012.
Zhang, T., Mackenzie, A. F., Liang, B., and Drury, C. F.: Soil test phosphorus and phosphorus fractions with long-term phosphorus addition and depletion, Soil Sci. Soc. Am. J., 68, 519-528, https://doi.org/10.2136/sssaj2004.5190, 2004.

Zhao, F., Zhang, Y., Dijkstra, F. A., Li, Z., Zhang, Y., Zhang, T., Lu, Y., Shi, J., and Yang, L.: Effect of amendments on phosphorous atatus in soils with different phosphorous levels, Catena, 172, 97-103, https://doi.org/10.1016/j.catena.2018.08.016, 2019.

Zhou, K., Sui, Y., Xu, X., Zhang, J., Chen, Y., Hou, M., and Jiao, $X$.: The effects of biochar addition on phosphorus transfer and water utilization efficiency in a vegetable field in Northeast China, Agr. Water Manage., 210, 324-329, https://doi.org/10.1016/j.agwat.2018.08.007, 2018. 